\title{
Distribution, Mobility and Fate of Trace Elements in an Estuarine System Under Anthropogenic Pressure: the Case of the Karstic Timavo River (Northern Adriatic Sea, Italy)
}

\author{
Elena Pavoni ${ }^{1,2}$ (D) Matteo Crosera ${ }^{1} \cdot$ Elisa Petranich ${ }^{2} \cdot$ Jadran Faganeli $^{3} \cdot$ Katja Klun $^{3} \cdot$ Paolo Oliveri $^{4}$. \\ Stefano Covelli ${ }^{2} \cdot$ Gianpiero Adami $^{1}$
}

Received: 30 August 2020 / Revised: 24 January 2021 / Accepted: 2 February 2021 / Published online: 14 February 2021

(C) The Author(s) 2021

\begin{abstract}
The accumulation of contaminants and their potential mobility represent two of the main environmental issues facing coastal environments. Sediments often act as "reservoirs" of contaminants, including potentially toxic trace elements, but they can also be considered a secondary source of contamination due to remobilisation processes at the sediment-water interface which may affect the quality of the coastal water and aquatic biota. This research aims to provide a geochemical characterisation of the estuarine system of the Timavo/Reka River, focusing on the occurrence of trace elements in different environmental matrices with the purpose of highlighting potential critical conditions in terms of environmental quality. The surface sediments were found to be enriched in several trace elements especially in the innermost sector of the area. There, sulphate-reductive conditions in the bottom saltwater testify to potential anoxia at the sediment-water interface, driving trace element accumulation in the residual fraction of the sediments. However, Fe and Mn redox behaviour appears to play a crucial role in the recycling of dissolved trace elements in the water column. With the lone exception of the saltwater in the innermost sector, trace elements were found to be mainly associated with suspended particles due to oxidation and precipitation processes, whereas a common lithogenic origin was identified for $\mathrm{Cr}$, Ni, and $\mathrm{Co}$, which are significantly correlated both in the surface sediments and in the suspended particles.
\end{abstract}

Keywords Trace elements $\cdot$ Sediment $\cdot$ Water quality $\cdot$ Principal component analysis $\cdot$ Estuary

\section{Introduction}

Estuaries are recognised worldwide as crucial aquatic systems where strong freshwater-seawater mixing occurs (Savenko et al. 2014; de Souza Machado et al. 2016; Fiket et al. 2018). The hydrodynamic processes governing the estuarine water circulation actively influence suspended particle

Communicated by Wen-Xiong Wang

Elena Pavoni

epavoni@units.it

1 Department of Chemical and Pharmaceutical Sciences, University of Trieste, Via L. Giorgieri 1, 34127 Trieste, Italy

2 Department of Mathematics and Geosciences, University of Trieste, Via E. Weiss 2, 34128 Trieste, Italy

3 Marine Biology Station, National Institute of Biology, Fornace 41, 6330 Piran, Slovenia

4 Department of Pharmacy, University of Genova, Viale Cembrano 4, I-16148 Genova, Italy transport and deposition (Meade 1972). In the estuarine mixing zone, the variations in flow velocity and the occurrence of sharp density and salinity gradients lead to fine particle aggregation and settling (Wright 1977; Menon et al. 1998). For this reason, estuaries can be considered a sedimentary trap. This is of relevant concern as suspended particulate matter (SPM) is known to play a crucial role in the transfer of potentially toxic trace elements and other contaminants in estuarine and coastal environments (Turner et al. 1991). In addition, trace elements are subjected to a variety of physicochemical and biogeochemical processes which may strongly affect their distribution, speciation and fate.

Marine coastal areas are often affected by high anthropogenic pressure due to extended urban areas and industrial, harbour and tourism activities (Casado-Martínez et al. 2006; Petranich et al. 2018b). The derived impact leads to the accumulation of contaminants including potentially toxic trace elements, organometallic compounds and persistent organic pollutants (e.g. Neto et al. 2006; Botwe et al. 2017). In this context, sediments are largely thought to act as a sink for several toxic compounds and are also of great concern, 
becoming a secondary source of contamination (e.g. Monterroso et al. 2007; Santos-Echeandia et al. 2009; Acquavita et al. 2010). Indeed, resuspension events due to tidal currents or caused by dredging operations (Wasserman et al. 2016; Silveira et al. 2017) and changes in the physicochemical boundary conditions at the sediment-water interface (SWI) (Piou et al. 2009) could lead to remobilisation and the subsequent release of potentially toxic trace elements in solution (Warnken et al. 2001; Caplat et al. 2005). The mobility of these contaminants is influenced by several factors including the chemical form in sediments, the redox state at the SWI, the microbial activity and the occurrence of organic matter (OM). Biogeochemical processes at the SWI could also be responsible for the transformation of contaminants into more toxic and dissolved bioavailable forms with a subsequent transfer to the aquatic trophic chain (Point et al. 2007; Siot et al. 2008; Kovač et al. 2018). These processes are usually enhanced in coastal environments characterised by shallow water, such as lagoons and semi-closed estuarine systems. Here, the increasing aerobic microbial activity often results in oxygen depletion favouring anoxic/hypoxic conditions at the SWI, which can lead to recycling processes of organic carbon and nutrients (e.g. De Vittor et al. 2012; Ospina-Alvarez et al. 2014; Petranich et al. 2018a). Permanent anoxic marine basins are relatively rare, and the Black Sea, the Baltic Sea and the Framvaren Fjord are the most well-known and investigated areas (Haraldsson and Westerlund 1988; Yao and Millero 1995; Dyrssen 1996). These particular environments are indeed characterised by a persistent oxygen stratification along the water column which render them of great interest from a biogeochemical point of view (McKee and Skei 1999). However, the scarce water circulation in restricted areas of semi-closed estuarine systems may also lead to the formation of an oxic-anoxic interface along the water column. Although this condition is not constant during the year and usually occurs during summer, these aquatic systems may represent useful natural laboratories in which to investigate the effects of anoxia on the biogeochemical cycles of trace elements.

The estuarine system of the Timavo/Reka River is a semiclosed aquatic system located in the northeastern sector of the Gulf of Trieste (northern Adriatic Sea, Italy). Little information is currently available on estuarine processes involving potentially toxic trace elements (Pavoni et al. 2020b) in the water column-sediment compartment and few previous studies have focused only on the water quality of the karstic freshwater (Reisenhofer et al. 1996, 1998). For this reason, the principal aim of this research is to provide a geochemical characterisation of this estuarine system looking for potential critical situations such as bottom anoxic/hypoxic conditions affecting the general quality of the environment. Trace element occurrence and distribution in distinct environmental matrices were investigated and supported by means of principal component analysis (PCA) in order to depict differences among the distinct sectors of the investigated area and to evaluate the potential mobility of trace elements between the water column and sediment compartments.

\section{Materials and Methods}

\section{Environmental Setting}

The Gulf of Trieste is a semi-closed shallow-water basin with a maximum water depth of $25 \mathrm{~m}$ in its central sector. The water in the central sector of the Gulf typically reports marine salinity values ranging between 33.0 and $38.5 \%$ in the surface water layer and between 36.0 and $38.5 \%$ at the bottom (Olivotti et al. 1986). The anticlockwise circulation of the Adriatic Sea dominates the water circulation in the Gulf (Malačič and Petelin 2009) and the interaction between freshwater river inputs and saltwater is often responsible for the formation of strong salinity gradients (25-38 PSU) (Cozzi et al., 2012).

The main freshwater input entering the Gulf of Trieste is represented by the Isonzo/Soča River (average flow rate of 82 $\mathrm{m}^{3} \mathrm{~s}^{-1}$ (Cozzi et al. 2012)), followed by the Timavo/Reka River (Table 1). The Timavo River has its origins in Croatia (Mount Snežnik, Slovenia-Croatia border area) and flows on flysch terrains in Slovenia before sinking into the Karst Plateau at the Škocjan Caves (Reisenhofer et al. 1998; Gabrovšek et al. 2018). After an underground path of approximately $38 \mathrm{~km}$, the river re-emerges from several springs (average discharge of $30.2 \mathrm{~m}^{3} \mathrm{~s}^{-1}$, Gabrovšek and Peric 2006) $2 \mathrm{~km}$ from the sea and flows into the Panzano Bay in the northwest sector of the Gulf of Trieste (Fig. 1).

Two additional channels (the Lòcavaz and the East-West channels) are located in the estuarine system of the Timavo River. The Lòcavaz channel flows near the highway in the northeast sector of the investigated area and contributes to the water supply of the estuary itself, whereas the East-West channel is artificial and closed (Fig. 1, Table 1).

The estuarine system of the Timavo River is subject to strong anthropogenic pressure. Firstly, the occurrence of $\mathrm{Hg}$ in the Gulf of Trieste and in the Bay of Panzano is well documented (Horvat et al. 1999; Covelli et al. 2001; Acquavita et al. 2010) since the Isonzo River is known to be the main source of particulate $\mathrm{Hg}$ (Covelli et al. 2007) due to long-term cinnabar $(\alpha-\mathrm{HgS})$ extraction activity at the Idrija mining district (Slovenia) (Hines et al. 2000). In addition, human activities increased during the twentieth century with rising mariculture, port and industrial activities. The investigated area is indeed home to a fish farm, shipyards and moorings for touring boats, sewage discharge and industrial settlements, including a papermill and a thermoelectric plant for the town of Monfalcone, which discharges cooling water (maximum threshold limit of $35{ }^{\circ} \mathrm{C}$ ) in the East-West water channel. 
Table 1 Summary of the information about the course of the Timavo/Reka River and the two channels (the Lòcavaz and the East-West channels) which contribute to the water supply at the esuarine system

\begin{tabular}{ll}
\hline & Timavo/Reka River \\
Origin & Mount Snežnik, Croatia \\
River course & Sinks into the Karst Plateau at the Škocjan Caves, Slovenia \\
& Underground river path of approximately $38 \mathrm{~km}$ \\
River springs & Gulf of Trieste, Panzano Bay, $2 \mathrm{~km}$ from the sea, Italy \\
Spring discharge & $\begin{array}{l}30.2 \mathrm{~m}^{3} \mathrm{~s}^{-1} \\
\text { Additional Water Supply in the Timavo/Reka Estuarine System }\end{array}$ \\
Lòcavaz channel & $\begin{array}{l}\text { Flows in the vicinity of a highway } \\
\text { East-West channel }\end{array}$ \\
& $\begin{array}{l}\text { Artificial and closed } \\
\text { Affected by the discharge of cooling water from the thermoelectric plant of Monfalcone } \\
\text { Conditions of oxygen depletion and anoxia in the bottom layer of the water column }\end{array}$ \\
\hline
\end{tabular}

The subsequent mixing between water masses of different temperature and salinity is extremely complex since the water circulation in the closed East-West channel is scarce, although partially affected by the tidal currents and the freshwater inputs provided by the Timavo River and the Lòcavaz channel. As a result, previous investigations highlighted conditions of oxygen depletion and anoxia at the SWI during the summer season in the area between sampling sites TV1 and TV2 where the fish farm is located (unpublished data). These observations represent an important environmental issue regarding the general water quality at the estuarine system of the Timavo River as pointed out by several studies focused on similar aquatic systems (e.g. Turner et al. 1987; Riedel et al. 1999; Petranich et al. 2018b).

\section{Sampling Strategy}

Water and sediment samples were collected at five sites in the estuarine system of the Timavo River in July 2018 (Fig. 1). In detail, by moving from the estuary mouth close to the Panzano Bay (TV5), samples were collected along the main branch of the Timavo River itself (TV4). Subsequently, water and sediments were sampled upstream from the confluence with the main branch of the Timavo River and in the vicinity of the

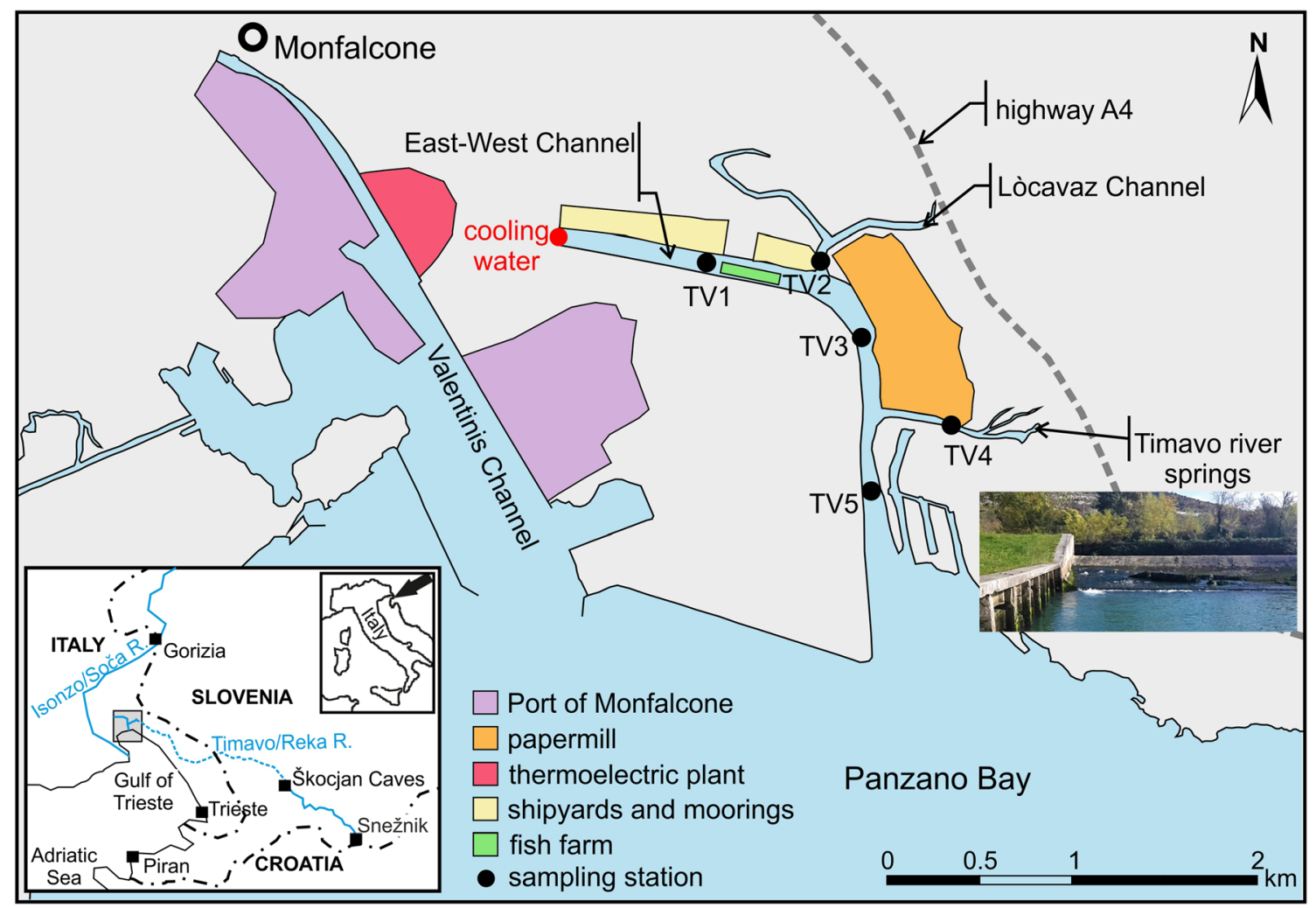

Fig. 1 Index map of the study area and location of the sampling sites at the estuarine system of the Timavo River 
papermill (TV3), at the confluence with the Lòcavaz channel (TV2) and along the East-West channel (TV1). The last two sampling sites (TV1 and TV2) represent the innermost sector of the investigated area.

Salinity (PSU, practical salinity unit), temperature $\left({ }^{\circ} \mathrm{C}\right)$ and turbidity (NTU, Nephelometric Turbidity Unit) vertical profiles were recorded using a CTD multiprobe $\left(\right.$ Hydrolab $\mathrm{H}_{2} \mathrm{O}$ with a $0.10 \mathrm{dbar}$ pressure step) before sampling. Surface freshwater and bottom saltwater were collected using a Niskin bottle (5-L capacity), and pH and redox-potential (Eh) were measured in situ by means of portable probes ( $\mathrm{pH}$ metre $\mathrm{PH} 25$ by Crison Instruments). Water sample aliquots for the analytical determination of dissolved trace elements and nutrients were filtered (Millipore Millex HA, $0.45-\mu \mathrm{m}$ pore size) in the field and collected in designated pretreated containers. Sample aliquots for trace element determinations were immediately acidified $(1 \% \mathrm{v} / \mathrm{v})$ with suprapure nitric acid $\left(\mathrm{HNO}_{3}, \geq 69 \%\right.$, VWR) to preserve sample composition whereas borosilicate glass containers were used to store water aliquots for the analysis of the dissolved $\mathrm{Hg}$ which were immediately oxidised with bromine chloride $(\mathrm{BrCl}, 0.50 \% \mathrm{v} / \mathrm{v}$, until the colour of the sample turned yellow) following the EPA Method 1631e (2002). In addition, glass microfiber filters (pretreated Whatman GF/F, ø $25 \mathrm{~mm}, 0.8-\mu \mathrm{m}$ pore size) were used to filtrate sample aliquots for the determination of dissolved organic carbon (DOC) and total dissolved nitrogen (TN) which were collected in glass containers.

All the water samples were stored in a portable cooler and, once in the laboratory, sample aliquots for $\mathrm{Hg}$ and other trace element determinations were stored in the dark at $4{ }^{\circ} \mathrm{C}$ whereas sample aliquots for $\mathrm{DOC}, \mathrm{TN}$ and nutrients were frozen until analysed.

Moreover, an additional sample aliquot of $2 \mathrm{~L}$ was taken to the laboratory where the suspended particles were separated in order to allow for the determination of trace elements in the SPM fraction.

Furthermore, surface sediments were collected by means of a stainless steel Van Veen grab $(1.5 \mathrm{~L})$. The first $2 \mathrm{~cm}$ of the sediment surface was promptly scraped off using a stainless steel spoon and homogenised on board the boat, collected in polyethylene containers, stored in an appropriately portable cooler and transported to the laboratory.

\section{Analytical Determinations: Dissolved Fraction}

With the lone exception of $\mathrm{Hg}$, dissolved trace elements (As, $\mathrm{Ba}, \mathrm{Co}, \mathrm{Cu}, \mathrm{Cs}, \mathrm{Cr}, \mathrm{Fe}, \mathrm{Ni}, \mathrm{Mn}, \mathrm{Pb}, \mathrm{V}$ and $\mathrm{Zn}$ ) were detected by means of inductively coupled plasma mass spectrometry (ICP-MS) using a NexION 350x Spectrometer (PerkinElmer, USA) equipped with an ESI SC Autosampler. The surface freshwater was directly analysed whereas the bottom saltwater samples were diluted 1:10 and acidified with $\mathrm{HNO}_{3}(1 \%)$ in order to avoid problems caused by elevated concentrations of salt (Pavoni et al. 2020a, b). The calibration curves were achieved by using standard solutions (ranging between 0.50 and $10 \mu \mathrm{g} \mathrm{L}^{-1}$ ) obtained by the dilution of a multistandard solution $\left(10 \mathrm{mg} \mathrm{L}^{-1}\right)$ for ICP analyses (Periodic Table MIX 1, Sigma-Aldrich). Kinetic energy discrimination (KED) mode was used in order to avoid and minimise cell-formed polyatomic ion interference. The limits of detection (LODs) are reported in Table $\mathrm{S} 1$ and the precision of the analysis expressed as RSD\% was $<3 \%$. Blank values were below LOD with the only exception being $\mathrm{Zn}$, which in some cases reached concentrations of approximately $0.50 \mu \mathrm{g} \mathrm{L}^{-1}$, as previously reported in other studies (e.g. Sigg et al. 2000).

The quality of the analysis and, especially, the matrix effect were evaluated by means of laboratory-fortified samples prepared by spiking 1 or $5 \mu \mathrm{g} \mathrm{L}^{-1}$ (depending on the trace element concentrations in the original sample) of the trace elements into the original estuarine water samples (Pavoni et al. 2020a, b). For this purpose, a different multistandard solution from that used for instrument calibration was employed and acceptable recoveries from 6 spiked samples were obtained ranging between 77 and $104 \%$ testifying to a negligible matrix effect. Moreover, laboratory-fortified blanks of $1 \mu \mathrm{g} \mathrm{L}^{-1}$ prepared by dilution of a multistandard solution $\left(10 \mathrm{mg} \mathrm{L}^{-1}\right)$ different from that used for instrument calibration were analysed every 10 samples in order to evaluate the instrument performance over time.

Dissolved $\mathrm{Hg}$ was determined by means of cold vapor atomic fluorescence spectrometry coupled with a gold trap pre-concentration system (CV-AFS Mercur, Analytic Jena). In detail, the analysis was performed through a pre-reduction using $\mathrm{NH}_{2} \mathrm{OH}-\mathrm{HCl}(250 \mu \mathrm{L} / 100 \mathrm{~mL}$ sample) until the yellow colour disappeared, followed by a reduction with $\mathrm{SnCl}_{2}(2 \%$ $\mathrm{v} / \mathrm{v}$ in $\mathrm{HCl} 2 \% \mathrm{v} / \mathrm{v}$ ) according to EPA Method 1631e (2002). The instrument was calibrated using standard solutions (ranging between 1 and $50 \mathrm{ng} \mathrm{L}^{-1}$ ) prepared by the dilution of a $\mathrm{Hg}$ standard solution (mercury standard solution, Merck Millipore, $\left.1000 \mathrm{mg} \mathrm{L}^{-1}\right)$ and acidified with $\mathrm{BrCl}(0.50 \%$ $\mathrm{v} / \mathrm{v}$ ). In addition, certified reference solution (ORMS-5, Canada) was analysed in the same batch as the estuarine water samples for quality control and acceptable recovery was obtained (105\%). The LOD was $0.60 \mathrm{ng} \mathrm{L}^{-1}$ and the precision of the analysis expressed as RSD\% was $<3 \%$.

The analytical determination of dissolved nutrients, including nitrate $\left(\mathrm{NO}_{3}{ }^{-}\right)$, nitrite $\left(\mathrm{NO}_{2}{ }^{-}\right)$, ammonia $\left(\mathrm{NH}_{4}{ }^{+}\right)$, soluble reactive phosphorous (SRP) and soluble reactive silicate (SRSi), was performed using a segmented flow autoanalyser (Bran + Luebbe QuAttro) following the method reported by Grasshoff et al. (1999) and modified for the specific instrument. The LODs were $0.02 \mu \mathrm{mol} \mathrm{L}{ }^{-1}$ for $\mathrm{NO}_{3}{ }^{-}, \mathrm{NO}_{2}{ }^{-}$and $\mathrm{NH}_{4}{ }^{+}$and $0.01 \mu \mathrm{mol} \mathrm{L}{ }^{-1}$ for SRP and SRSi. Certified standard solutions (Inorganic Ventures Standard Solutions and MOOS-2, NRC) were used for quality control. Recoveries of at least 10 replicates of certified standard solutions were 
101, 96.0, 102, 97.2 and $97.4 \%$ for $\mathrm{NO}_{2}, \mathrm{NO}_{3}, \mathrm{NH}_{4}$, SRP and SRSi, respectively. Furthermore, proficiency testing (PT) exercises proposed by the European network of PT providers (QUASIMEME programmes AQ1 and AQ2) were periodically performed to ensure the accuracy of the analytical performance.

Dissolved organic carbon (DOC) and TN were analysed by means of a high-temperature catalytic method using TOC-L Shimadzu analyser (Sugimura and Suzuki 1998). The instrument was calibrated using potassium phthalate and quality control was ensured by analysing certified reference material (Consensus Reference Material, University of Miami, Florida). The precision of the method expressed as RSD\% was $<3 \%$.

\section{Analytical Determinations of the Solid Matrix: Sediments and Suspended Particles}

After freezing and freeze-drying (CoolSafe 55-4 SCANVAC), both chemical and grain size analyses were performed on the sediment samples. For grain size determination, 15-20 g of each sediment sample was treated with hydrogen peroxide $\left(\mathrm{H}_{2} \mathrm{O}_{2}, 3 \%\right)$ for $24 \mathrm{~h}$ to eliminate the majority of the organic matter. Subsequently, the samples were wet-sieved through a 2-mm sieve and the resulting $<2-\mathrm{mm}$ fraction was analysed by means of a laser granulometer (Malvern Mastersizer 2000).

For trace element determination, sediments were sieved to $<2 \mathrm{~mm}$, finely ground and acid-digested in PTFE vessels through a total dissolution in a closed microwave system (Multiwave PRO, Anton Paar) using inverse aqua regia (suprapure $\mathrm{HNO}_{3} \geq 69 \%$ and hydrochloric acid $\mathrm{HCl} \geq 37 \%$, 3:1) and hydrofluoric acid (HF, 50\%) (EPA Method 3052, 1996). Two heating steps were performed for the mineralisation and boric acid $\left(\mathrm{H}_{3} \mathrm{BO}_{3}, 6 \%\right)$ was added in order to buffer the excess amount of HF in the second step. After mineralisation, the solutions were diluted up to a volume of 25 $\mathrm{mL}$ by adding Milli-Q water and filtered (Millipore Millex HA, $0.45-\mu \mathrm{m}$ pore size) before analysis.

In addition, the adsorption of trace elements on the surface of the finest fraction of sediment as well as their amount associated with $\mathrm{Fe}$ and $\mathrm{Mn}$ oxy-hydroxides, carbonates and phosphates was evaluated by performing a weak extraction ( $\mathrm{HCl}, 0.5 \mathrm{M}$ ) (Adami et al. 1999). For this purpose, $2 \mathrm{~g}$ of sediment and $20 \mathrm{~mL}$ of the extraction solution were rotated at room temperature for $18 \pm 2 \mathrm{~h}$. Samples were then centrifuged (3000 rpm for $10 \mathrm{~min}$ ) and the obtained solutions were filtered (Millipore Millex HA, $0.45-\mu \mathrm{m}$ pore size) and diluted up to a final volume of $25 \mathrm{~mL}$ by adding Milli-Q water.

The SPM concentrations were measured via vacuum filtration of the estuarine water samples through pre-conditioned and pre-weighed membrane filters (Millipore HA, ø $47 \mathrm{~mm}$, $0.45-\mu \mathrm{m}$ pore size). Subsequently, filters were acid-digested using inverse aqua regia $\left(\mathrm{HNO}_{3} \geq 69 \%\right.$ and $\mathrm{HCl} \geq 37 \%$, 3:1) according the modified EPA Method 3052 (1996) and the obtained solutions were treated in the same manner described for the sediment samples.

The concentrations of major ( $\mathrm{Al}$ and $\mathrm{Fe}$ ) and trace (As, $\mathrm{Co}$, $\mathrm{Cu}, \mathrm{Cs}, \mathrm{Cr}, \mathrm{Hg}, \mathrm{Ni}, \mathrm{Mn}, \mathrm{Pb}$ and $\mathrm{Zn}$ ) elements in sediments (total and extracted samples) and in the SPM were detected by means of inductively coupled plasma optical emission spectrometry (ICP-OES) using an Optima 8000 Spectrometer (PerkinElmer, USA) equipped with a S10 Autosampler (PerkinElmer, USA) and inductively coupled plasma mass spectrometry (ICP-MS, NexION 350x equipped with an ESI $\mathrm{SC}$ autosampler, PerkinElmer), respectively. In the case of trace element analysis, the instrument was calibrated using standard solutions prepared by the dilution of multistandard solutions ranging between 0.50 and $500 \mu \mathrm{g} \mathrm{L}^{-1}$ and between 0.01 and $5 \mu \mathrm{g} \mathrm{L}^{-1}$ in the case of $\mathrm{Hg}$. The instrument settings and quality control were conducted according to the same criteria described for the analysis of the dissolved fraction and the precision of the analyses expressed as RSD\% were $<5$ and $3 \%$ for ICP-OES and ICP-MS, respectively. Moreover, certified reference material (PACS-3 Marine Sediment Certified Reference Materal, NRCC, Canada) was digested in the same batch as the sediment samples to ensure the accuracy of the procedure. Acceptable recoveries were obtained varying between 104 and 116\%.

\section{Exploratory Multivariate Data Analysis}

Experimental data were analysed by principal component analysis (PCA), as an unsupervised exploratory tool for the visual identifications of relationships within samples (PC scores and score plots), within variables (PC loadings and loading plots) and between samples and variables (biplots) (Oliveri et al. 2020). Prior to multivariate analysis, data matrices were pre-processed via the application of column autoscaling, aimed at minimising systematic differences (e.g. scale effects) between the experimental variables (Oliveri et al. 2019). Multivariate data processing was performed using the CAT (Chemometric Agile Tool) package, based on the R platform (The R Foundation for Statistical Computing, Vienna, Austria) and freely distributed by Gruppo Italiano di Chemiometria (Italy) (Leardi et al. 2019).

\section{Results and Discussion}

\section{Water Column Characterisation}

The vertical variability of the main physico-chemical parameters (turbidity, salinity and temperature) is depicted in Fig. 2. The estuarine system of the Timavo River showed an evident salt-wedge intrusion and a sharp halocline was recorded at 


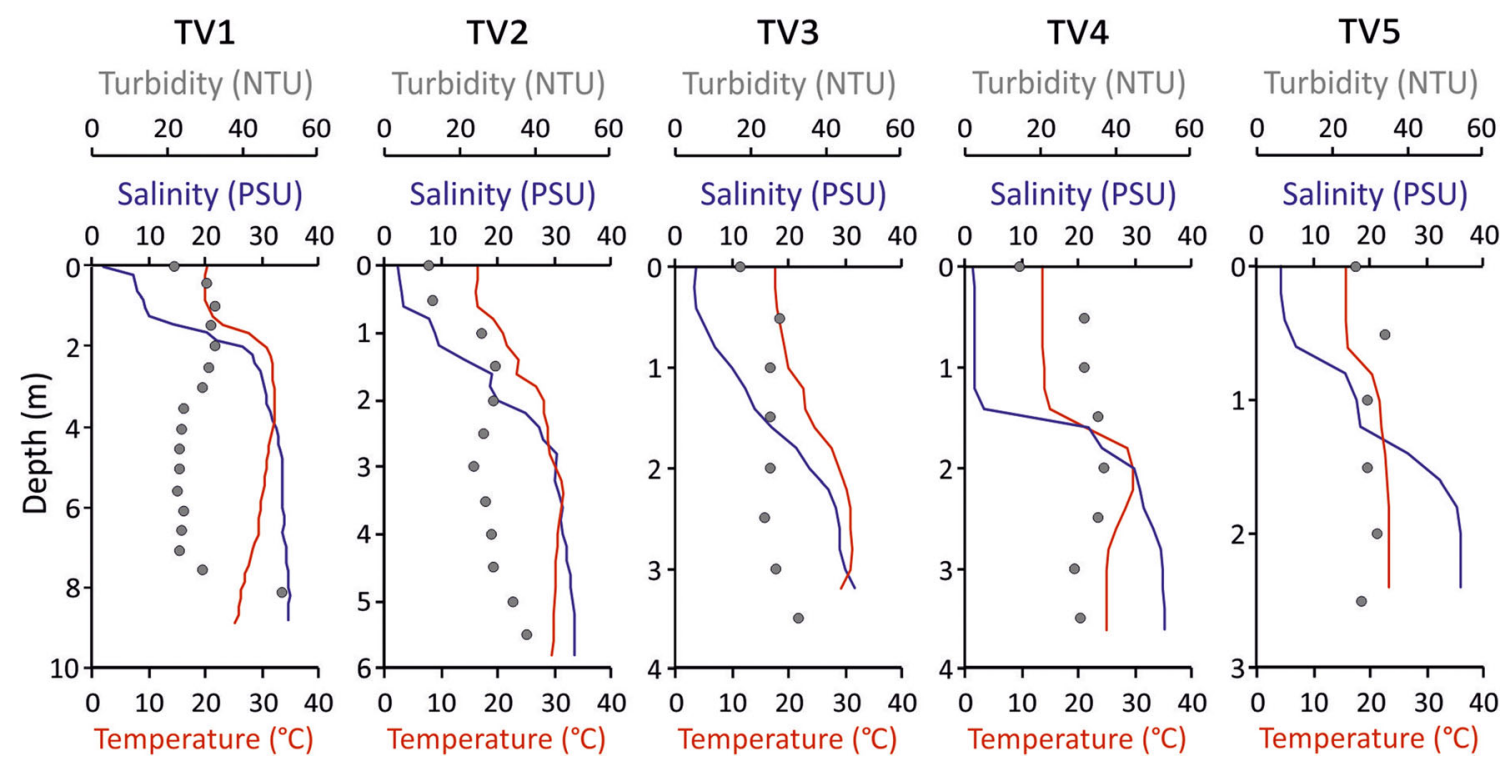

Fig. 2 Vertical profiles of turbidity (NTU, grey dots), salinity (PSU, blue line) and temperature $\left({ }^{\circ} \mathrm{C}\right.$, red line) recorded at the estuarine system of the Timavo River

different sampling sites. Although site TV4, which is representative of the main branch of the Timavo River, displayed a strong prevalence of freshwater showing a thickness of approximately $1.5 \mathrm{~m}$, the salinity generally increased with depth reaching values typical of marine water at the bottom (34.3 PSU). On the other hand, an increased mixing between riverine and marine water was clearly evident at site TV3 (28.8 PSU at the bottom) due to the interaction between the saltwedge intrusion and the freshwater inputs provided by the Timavo River and the Lòcavaz channel. A similar condition of mixing was also recorded at site TV2, where the halocline is less evident, as well as at the estuary mouth (TV5), where the salinity gradient appears to be more affected by the coastal saltwater (35.0 PSU at the bottom). Conversely, mixing processes between different water masses did not occur at site TV1 where the halocline was sharp due to the limited water circulation in the closed East-West channel.

At sites TV1 and TV2, turbidity showed values of approximately 20 NTU in the surface freshwater, slightly increased to 25-30 NTU along the water column reaching values of 40$50 \mathrm{NTU}$ at the bottom, most likely due to resuspension caused by the salt-wedge intrusion. Conversely, turbidity values were quite constant with increasing depth (25-30 NTU) at sites TV3, TV4 and TV5.

Due to the discharge of cooling water from the Monfalcone thermoelectric plant at the end of the East-West channel, warm water was found in the mixing water layer (between a depth of 3 and $4 \mathrm{~m}$ ), reaching maximum values in the innermost sector of the area (equal to 32.1 and $31.4{ }^{\circ} \mathrm{C}$ at sites TV1 and TV2, respectively). The increase in temperature was also quite evident at site TV3 ( $30.3^{\circ} \mathrm{C}$ between 2 and $3 \mathrm{~m}$ depth). Conversely, the main branch of the Timavo River (TV4) and the estuary mouth (TV5) showed relatively lower values (27.1
${ }^{\circ} \mathrm{C}$ and $23.4{ }^{\circ} \mathrm{C}$ between a depth of 2 and $3 \mathrm{~m}$ at TV4 and TV5, respectively), as the result of dilution effects related to the increasing mixing conditions between river freshwater and saltwater.

Despite significant differences in terms of $\mathrm{pH}$ not being recorded, the bottom water layer generally showed higher values of $\mathrm{pH}$, as a consequence of the presence of the saltwedge intrusion. The highest differences between the surface and the bottom water layers were measured at sites TV3, TV4 and TV5, where the freshwater contribution prevailed. The redox potential showed a gradual increase by moving from the innermost sampling sites (TV1 and TV2) to the estuary mouth (TV5), both in the surface and at the bottom. Although significant differences between distinct water masses were not observed at sites TV3, TV4 and TV5, where oxidising conditions prevailed, reductive conditions were found in the marine water of the innermost sampling sites. Indeed, Eh of -341 and $-15 \mathrm{mV}$ were measured at the bottom of TV1 and TV2 respectively, thus testifying to potential anoxic conditions at the SWI. On the contrary, the surface freshwater showed more oxidising conditions (12 and $45 \mathrm{mV}$ in TV1 and TV2, respectively). The dissolved oxygen was unfortunately not detected during sampling. However, quite low oxygenation (2.87 and $4.69 \mathrm{mg} \mathrm{L}^{-1}$ at sites TV1 and TV2, respectively) and redox potential (32.7 and $31.4 \mathrm{mV}$ at sites TV1 and TV2, respectively) were measured in the marine water during an additional survey performed in November 2018 and related to another study (Pavoni et al. 2020b). Conditions of anoxia were also detected in summer 2020 at site TV1 where 2.26 and $2.31 \mathrm{mg}$ $\mathrm{L}^{-1}$ were measured in the bottom saltwater (unpublished data). Moreover, previous investigations focused on the East-West channel (unpublished data) indicated very low values of dissolved oxygen at the bottom $\left(1.0\right.$ and $0.2 \mathrm{mg} \mathrm{L}^{-1}$ in summer 
2003 at sites TV1 and TV2, respectively) most likely due to the high content of organic matter from the nearby fish farm.

\section{Surface Sediments: Grain Size Composition and Occurrence of Trace Elements}

Grain size was found to be different among sampling sites despite the sediment collected at sites TV1 and TV2 showing very similar grain size spectra and composition (Figure S1). According to Shepard's (1954) classification, the sediment consisted mostly of silt (82.6 and $82.0 \%$ at sites TV1 and TV2, respectively) and showed the highest percentage of clay at sites TV1 $(8.68 \%)$ and TV2 $(6.60 \%)$, respectively. The sandy fraction was less represented and clearly increased by moving from the innermost area (represented by sites TV1 and TV2) to the external sector (TV5, 92.8\%).

The surface sediments showed trace element concentrations that often exceeded the Italian regulatory threshold limits (Decrees of the Italian Ministry of the Environment 260/2010 and 172/2015 according to EU Directive 2000/60/EC) for sediments of marine and transitional aquatic systems (Table S2, Figure S2). Nickel and $\mathrm{Cr}$ reached the maximum values at site TV4 (109 and $216 \mu \mathrm{g} \mathrm{g}^{-1}$, respectively) exceeding the threshold limit values of 30 and $50 \mathrm{\mu g} \mathrm{g}^{-1}$ in the whole study area. Moreover, $\mathrm{Hg}$ levels were found to notably exceed the threshold limit value $\left(0.30 \mu \mathrm{g} \mathrm{g}^{-1}\right)$ with the only exception being the mouth of the estuary $\left(0.08 \mu \mathrm{g} \mathrm{g}^{-1}\right.$ at site TV5). Arsenic, $\mathrm{Cd}$ and $\mathrm{Pb}$ slightly exceeded the threshold limit values (12, 0.3 and $30 \mu \mathrm{g} \mathrm{g}^{-1}$ for $\mathrm{As}, \mathrm{Cd}$ and $\mathrm{Pb}$, respectively) only at sites TV1 and TV2.

Trace element contents were found to be notably lower than those reported for the tourist port area of San Rocco (Italian sector of the Gulf of Trieste) and comparable to those reported for the nearby the Panzano Bay, the marina of Lucija (Slovenian sector of the Gulf of Trieste) and with the exception of $\mathrm{Hg}$, slightly higher than those measured in front of the Isonzo River mouth (Acquavita et al. 2010; Petranich et al. 2018b) (Table 2).

The occurrence of $\mathrm{Cr}$ and $\mathrm{Ni}$ in the easternmost sector of the Gulf of Trieste was previously reported (Faganeli et al. 1991; Covelli and Fontolan 1997) and evident anthropogenic inputs for these two elements have not yet been identified (Acquavita et al. 2010) suggesting that the suspended particles transported by the river inputs may act as their main source (Pavoni et al. 2020b). Indeed, $\mathrm{Cr}$ and $\mathrm{Ni}$ are of lithogenic origin as the result of alteration processes of the flysch formation outcropping in the continental area (Lenaz and Princivalle 1996; Zupančič and Skobe 2014). Moreover, in the case of the Timavo River basin, $\mathrm{Cr}$ and Ni may also originate from alteration processes of the $\mathrm{Cr}$-spinel enclosed in the bauxite veins found in the Late Maastrichtian-Paleocene bauxite layer (Lenaz et al. 2002). Runoff and erosion from the flysch formation would then be responsible for the enrichment of $\mathrm{Cr}$ and
$\mathrm{Ni}$ in the fine suspended load carried by the Timavo River. Alteration processes of flysch terrain may also be the source of Co (Frančišković-Bilinski et al. 2014) although reaching lower concentrations (10.1-16.9 $\mathrm{\mu g} \mathrm{g}^{-1}$ ) compared to those reached by $\mathrm{Cr}$ and $\mathrm{Ni}$. The maximum concentrations of $\mathrm{Cr}$ $\left(216 \mu \mathrm{g} \mathrm{g}^{-1}\right)$, Ni $\left(109 \mu \mathrm{g} \mathrm{g}^{-1}\right)$ and Co $\left(16.9 \mu \mathrm{g} \mathrm{g}^{-1}\right)$ were found at site TV4, and the strong correlations between these elements ( $r=0.989, n=5, P<0.01$ between $\mathrm{Cr}$ and Ni; $r=0.841$, $n=5, P<0.1$ between $\mathrm{Cr}$ and $\mathrm{Co} ; r=0.885, n=5, P<0.05$ between $\mathrm{Ni}$ and $\mathrm{Co}$ ) further confirmed their common lithogenic origin (Figure $\mathrm{S} 3$ ).

However, the potential anthropogenic contribution and the degree of contamination in the surface sediments cannot be fully assessed through the total concentration of one or more contaminants. Indeed, disparities in grain size and mineralogical composition are also important factors defining the state of the quality of the bottom sediments. In this research, the enrichment factors (EFs) were calculated using linear regression parameters between trace elements $(\mathrm{Cr}, \mathrm{Cu}, \mathrm{Fe}, \mathrm{Ni}, \mathrm{Pb}$ and $\mathrm{Zn}$ ) and $\mathrm{Al}$ as proposed by Covelli and Fontolan (1997). Conversely, in the case of $\mathrm{Hg}$, the EFs were calculated according to the following equation (1)

$\mathrm{EF}=(\mathrm{Me} / \mathrm{Al})_{\text {sample }} /(\mathrm{Me} / \mathrm{Al})_{\text {background }}$

where the background level corresponds to the average $\mathrm{Hg}$ concentration found in the uncontaminated levels of the deepest sections of three sediment cores from the Gulf of Trieste (Covelli et al. 2006). The results are reported following the five classes proposed by Sutherland (2000) (Table 3). According to this classification, the highest enrichment was reached by $\mathrm{Hg}(\mathrm{EF}=24.2)$ in the East-West channel (TV1) and decreased to significant (at sites TV2 and TV3) and moderate (at sites TV4 and TV5) by moving towards the mouth of the estuary. The occurrence of $\mathrm{Hg}$ can be related to the role of the Isonzo River, which is known to be the primary source of particulate $\mathrm{Hg}$ entering the Gulf of Trieste (Covelli et al. 2007). In fact, it has been demonstrated that stream losses from the Isonzo River, especially under conditions of low discharge, may act as one of the main sources of groundwater in the unconfined aquifer of the Isonzo River alluvial plain (Cerovac et al. 2018) and influence the Classical Karst groundwater (Doctor et al. 2000; Calligaris et al. 2018). Consequently, despite the hydrochemical seasonal variability of the discharge at the Timavo River springs is mainly related to the hydrochemical variability of the upper course of the river (Cucchi et al. 1997), the occurrence of $\mathrm{Hg}$ suggests that mixing processes involving Isonzo River freshwater and Timavo River groundwater could occur. On the other hand, it cannot be excluded that the high concentrations of $\mathrm{Hg}$ in sediments may be related to the role of the tidal currents. Indeed, resuspension events occurring in the Panzano Bay $\left(\mathrm{THg}=5.54 \mu \mathrm{g} \mathrm{g}^{-1}\right.$, Acquavita et al. 2010) lead to the transport 


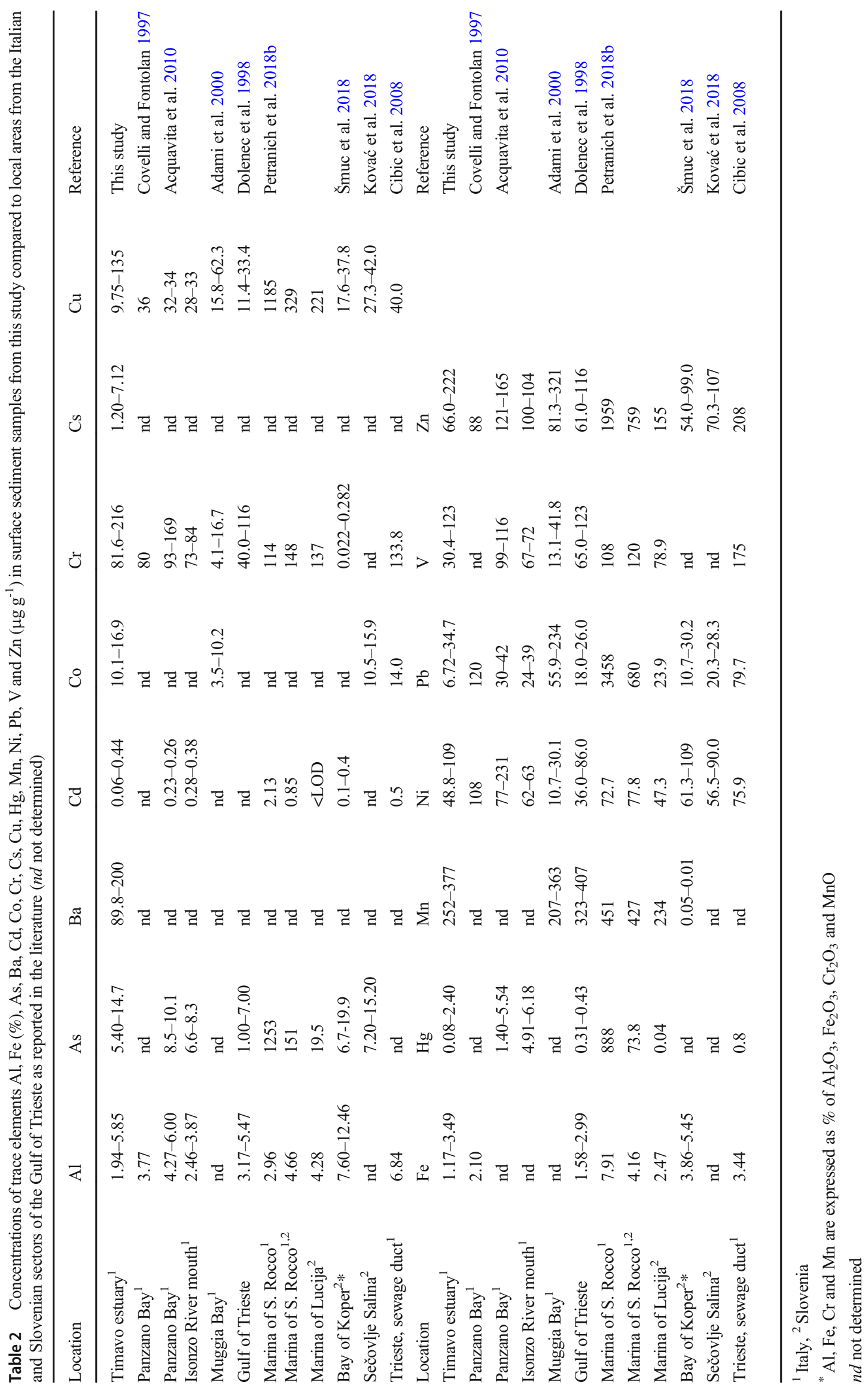


Table 3 Enrichment factors (EFs) for $\mathrm{Cr}, \mathrm{Cu}, \mathrm{Fe}, \mathrm{Hg}, \mathrm{Ni}, \mathrm{Pb}$ and $\mathrm{Zn}$ in the surface sediments collected at the estuarine system of the Timavo River. The classification proposed by Sutherland (2000) was applied

\begin{tabular}{lccccccc}
\hline \multicolumn{1}{c}{ Site } & $\mathrm{Cr}$ & $\mathrm{Cu}$ & $\mathrm{Fe}$ & $\mathrm{Hg}$ & $\mathrm{Ni}$ & $\mathrm{Pb}$ & $\mathrm{Zn}$ \\
\hline TV1 & 1.38 & 4.28 & 1.13 & 24.2 & 0.63 & 0.36 & 2.78 \\
TV2 & 1.46 & 2.74 & 1.06 & 10.3 & 0.74 & 0.33 & 2.13 \\
TV3 & 2.17 & 1.99 & 1.00 & 12.3 & 0.79 & 0.21 & 1.53 \\
TV4 & 2.54 & 1.77 & 1.11 & 4.04 & 0.96 & 0.23 & 1.51 \\
TV5 & 2.05 & 0.62 & 1.05 & 1.94 & 0.52 & 0.09 & 1.44 \\
\hline
\end{tabular}

EF (Sutherland, 2000)

$<2$ deficiency to low enrichment

2-5 moderate enrichment

5-20 significant enrichment

$20-40$ very high enrichment

$>40$ extremely high enrichment

of $\mathrm{Hg}$ associated with the finest fraction of the suspended particles into the Timavo estuarine system. Here, low hydrodynamic conditions may favour the settling of the suspended particles and accumulate this contaminant at the bottom.

In the case of $\mathrm{Cu}$, the EFs testified to moderate enrichment and achieved the maximum values at sites TV1 $(\mathrm{EF}=4.28)$ and TV2 $(E F=2.74)$ followed by a clear decrease in the EF values by moving from the innermost sector towards the estuary mouth. A similar trend was observed for $\mathrm{Zn}$ which showed a moderate enrichment at sites TV1 $(\mathrm{EF}=2.78)$ and TV2 (2.13). The innermost sector of the investigated area (sites TV1 and TV2) is home to shipyards and moorings for touring boats which can be a valid explanation for the enrichment in $\mathrm{Cu}$ and $\mathrm{Zn}$ in the sediment.
Chromium displayed a moderate enrichment only at sites TV3, TV4 and TV5 reaching the maximum value in the main branch of the Timavo River ( $\mathrm{EF}=2.54$ at site TV4). As previously mentioned, the Timavo River has been identified as the primary source of this element and the enrichment in $\mathrm{Cr}$ in the surface sediments may be due to the settling and subsequent accumulation at the bottom of the SPM transported by the river.

As an additional chemometric support, principal component analysis (PCA) was performed on chemical (total and extracted concentrations of trace elements) and grain size data in order to reveal differences among the investigated sampling sites. PCA was executed after column autoscaling and $87.7 \%$ of the total variance was explained by PC1 and PC2. The PCA output (Fig. 3) clearly denotes that several trace elements are
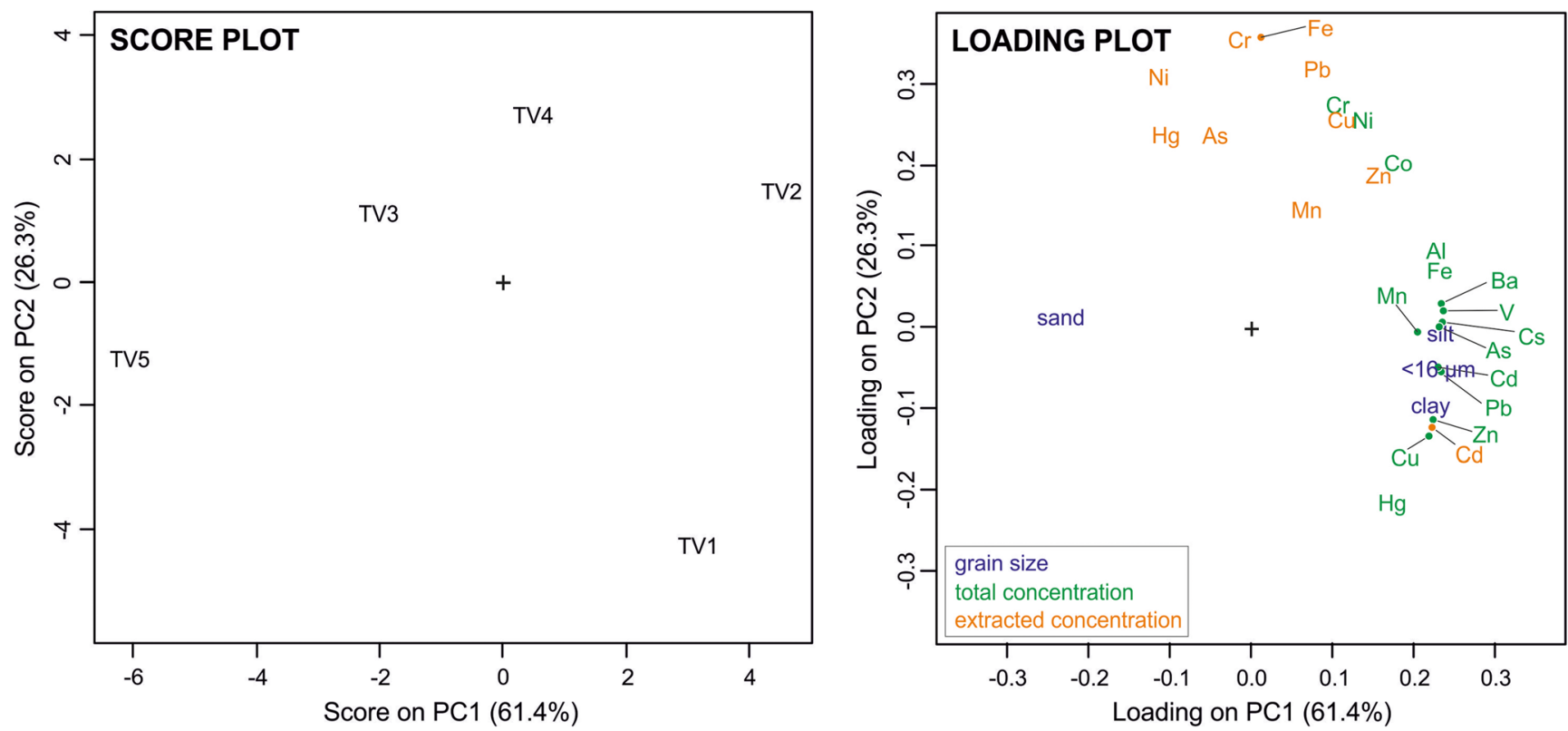

Fig. 3 Score and loading plots resuming the results of PCA performed on grain size composition, total and extracted trace element concentrations detected in the surface sediments collected at the estuarine system of the Timavo River 
strongly associated with the silty-clay fraction, which prevailed at sites TV1 and TV2. Conversely, total trace element concentrations were significantly low near the estuary mouth (site TV5), where the sediment consists mostly of sand. This trend is markedly evident for $\mathrm{Hg}$, which reached a value of $2.40 \mu \mathrm{g} \mathrm{g}^{-1}$ in the East-West channel (site TV1) and gradually decreased to a concentration of $0.08 \mu \mathrm{g} \mathrm{g}^{-1}$ at the mouth of the estuary (site TV5). According to several authors (e.g. Covelli et al. 2001; Yao et al. 2016), the clay and fine silt fractions $(<16 \mu \mathrm{m})$ exhibited the highest adsorption capacities for several trace elements. This is in agreement with the results of this research due to the strong positive correlations between total trace element contents and the $<16-\mu \mathrm{m}$ fraction (Figs. 3 and S4).

\section{Potential Mobility of Toxic Trace Elements from the Surface Sediments to the Water Column}

Sediments act as a sink and also a secondary source of contaminants due to remobilisation processes that occur at the SWI (e.g. Caplat et al. 2005; Zonta et al. 2019), thus also affecting water quality as well as the aquatic biota.

In this context, the total concentration is often not enough to clearly assess the potential environmental risk related to the occurrence of potentially toxic trace elements stored in sediments (Gleyzes et al. 2002; Zonta et al. 2019). Indeed, the chemical form is one of the main factors affecting the potential release of the labile fraction of trace elements and other contaminants from sediments to porewaters and to the water column (Riedel et al. 1999; Eggleton and Thomas 2004). Moreover, the boundary conditions, especially the redox state, also play a crucial role in regulating trace element mobility and bioavailability (Riedel et al. 1999; Shaheen et al. 2017). For this reason, single or sequential extractions are generally applied to investigate the potential mobility of contaminants from sediments to the overlying water (Adami et al. 1999, 2000; Gleyzes et al. 2002; Sahuquillo et al. 2003). Generally, the labile fraction of several trace elements (As, $\mathrm{Cu}, \mathrm{Fe}, \mathrm{Hg}, \mathrm{Mn}, \mathrm{Ni}$ and $\mathrm{Pb}$ ) increases by moving from the East-West channel (TV1) to the estuary mouth, thus testifying to the presence of more available chemical forms in the estua rine system moving down trea m $(\mathrm{Mn}>\mathrm{Pb}>\mathrm{Cu}>\mathrm{Cd}>\mathrm{Fe}>\mathrm{Ni}>\mathrm{Zn}>\mathrm{As}>\mathrm{Hg}>\mathrm{Cr}$ at site TV5) (Table S3 and Fig. 3). A significant increase is evident for $\mathrm{Hg}$, the labile percentage of which varies between $0.05 \%$ (at site TV1) and $13.6 \%$ (at site TV5). This result is of serious concern as anoxic surface sediments may act as a significant source of the more toxic and potentially bioaccumulable form of $\mathrm{Hg}$ (methylmercury) (Bloom et al. 1999; Mason et al. 2006; Emili et al. 2014; Cossa et al. 2017).

Other trace elements such as $\mathrm{As}, \mathrm{Cr}$ and $\mathrm{Ni}$ achieved the maximum labile percentages at site TV5 (19.2, 10.7 and 45.6 $\%$ for $\mathrm{As}, \mathrm{Cr}$ and $\mathrm{Ni}$ ), whereas scarce mobility was observed for most of the investigated trace elements $(\mathrm{Cr}<\mathrm{Pb}<\mathrm{Fe}<\mathrm{Hg}<\mathrm{Cu}<\mathrm{As}<\mathrm{Ni}<\mathrm{Zn}<\mathrm{Cd}<\mathrm{Mn})$ at site $\mathrm{TV} 1$ most likely due to the prevalence of refractory phases such as sulphides or strong bindings with OM (Sahuquillo et al. 2003; Emili et al. 2016). Conversely, although reductive conditions occurred $(E h=-15 \mathrm{mV})$, slightly higher levels of labile trace elements were observed at site TV2 $(\mathrm{Pb}>\mathrm{Cu}>\mathrm{Mn}>\mathrm{Zn}>\mathrm{Cd}>\mathrm{Fe}>\mathrm{Ni}>\mathrm{As}>\mathrm{Cr}>\mathrm{Hg})$. In this case, reductive conditions at the SWI might have been responsible for the reduction of $\mathrm{Fe}$ and $\mathrm{Mn}$ oxy-hydroxides with the subsequent release in solution of the associated trace elements (Mason et al. 2006). Since the reduction of Mn and Fe oxyhydroxides usually occurs in the first centimetres of the bottom sediments, dissolved $\mathrm{Fe}, \mathrm{Mn}$ and trace elements in the porewater profiles often reach their maximum concentration in the surface layer of sediments. These processes may promote effluxes of the trace elements at the SWI where sediments are depleted in their mobile phases (Warnken et al. 2001; Caplat et al. 2005). A similar situation was identified in a tourist port area in the Gulf of Trieste where high percentages of the labile trace elements were reached in the sediments, although total trace element contents were relatively low (Petranich et al. 2018b).

\section{Dissolved Nutrients and Trace Elements}

The distribution of dissolved trace elements and nutrients in the estuarine system of the Timavo River was evaluated by means of PCA. After column autoscaling, $82.5 \%$ of the total variance was explained by PC1 and PC2. Significant disparities in the concentrations of DOC and TN were not observed along the water column and among different sampling sites (Table S4, Fig. 4). The DOC:TN molar ratio was found to be higher at the bottom and lower than 10 , attesting to the marine origins of the $\mathrm{OM}$.

The PCA output (Fig. 4) clearly denotes the difference between the surface freshwater and the bottom saltwater. Oxidative conditions occurred in the surface freshwater which was dominated by the presence of $\mathrm{NO}_{3}{ }^{-}$which appears to be the prevalent form of dissolved inorganic nitrogen (DIN) (99.5-100\%) whereas $\mathrm{NH}_{4}^{+}(0.01-0.24 \%)$ and $\mathrm{NO}_{2}^{-}(0.01-$ $0.22 \%$ ) were less represented (Table S4). Surface freshwater samples also showed the highest concentrations of $\mathrm{Ba}$ (15.223.3 $\left.\mu \mathrm{g} \mathrm{L}^{-1}\right)$, TN $\left(83.8-96.8 \mu \mathrm{mol} \mathrm{L}^{-1}\right)$ and SRSi (73.9$\left.99.8 \mu \mathrm{mol} \mathrm{L}^{-1}\right)$.

Conversely, strong reducing conditions $(\mathrm{Eh}=-341 \mathrm{mV})$ were observed at the bottom at site TV1 where hydrogen sulphide $\left(\mathrm{H}_{2} \mathrm{~S}\right)$ occurs within the water column due to reduction processes mediated by sulphate-reducing bacteria (Froelich et al. 1979; Tribovillard et al. 2006). According to Tribovillard et al. (2006), anoxic conditions in the water column may be favoured by scarce water circulation and renewal and are typical of confined aquatic systems where dissolved 

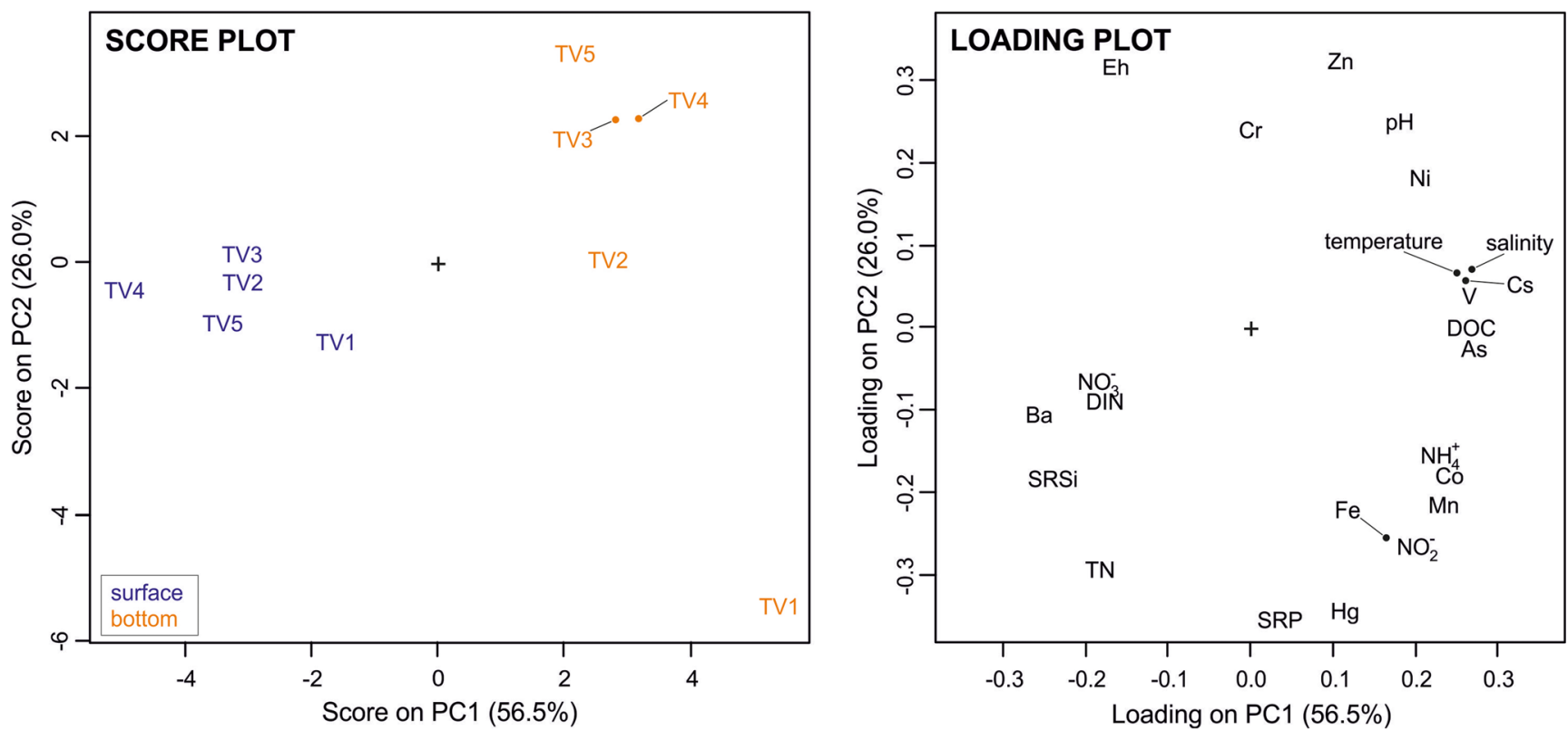

Fig. 4 Score and loading plots summarising the results of PCA performed on physico-chemical parameters, dissolved concentrations of trace element, nutrients, DOC and TN detected in the surface and bottom water samples collected at the estuarine system of the Timavo River

oxygen is consumed by intense OM degradation. Although the sampling performed in this study only provides a snapshot of these processes, the occurrence of a certain amount of $\mathrm{H}_{2} \mathrm{~S}$ above the SWI at site TV1 could allow for the precipitation of sulphides and the subsequent storage of trace elements into the residual fraction of the sediments (Huerta-Diaz and Morse 1992; Tribovillard et al. 2006; Scholz et al. 2013). This is in agreement with the results of the weak extraction performed on the sediment samples that did not reveal significant trace element mobility at site TV1.

However, the bottom saltwater displayed elevated concentrations of dissolved $\mathrm{Mn}\left(366 \mu \mathrm{g} \mathrm{L}^{-1}\right)$ and $\mathrm{Fe}\left(25.6 \mu \mathrm{g} \mathrm{L}^{-1}\right)$, followed by As $\left(2.97 \mu \mathrm{g} \mathrm{L}^{-1}\right)$ and $\mathrm{Hg}\left(5.10 \mathrm{ng} \mathrm{L}^{-1}\right)$ at site TV1 (Table S5). This evidence could be related to the redox behaviour of $\mathrm{Fe}$ and $\mathrm{Mn}$ oxy-hydroxides which are thought to play a crucial role in regulating dissolved trace element concentrations. Indeed, the geochemical behaviour of $\mathrm{Fe}$ and $\mathrm{Mn}$ are strictly connected (Tribovillard et al. 2006; Dellwig et al. 2010) although two main differences occur: (a) Fe is efficiently involved in sulphide precipitation whereas Mn does not show the same affinity to organic or sulphide phases (Huerta-Diaz and Morse 1992; Algeo and Maynard 2004) and (b) Fe and $\mathrm{Mn}$ display different oxidation kinetics since the Fe oxidation process is faster (Konovalov et al. 2004; Tribovillard et al. 2006). According to Konovalov et al. (2004), the redox cycling of $\mathrm{Fe}$ and $\mathrm{Mn}$ in stratified (oxicanoxic) water column is driven by two fundamental processes which appear to occur in the innermost sector of the Timavo estuarine system: the oxidation of $\mathrm{Mn}$ (II) and $\mathrm{Fe}(\mathrm{II})$ in the upper oxic layer and the reduction-dissolution processes of sinking Fe and Mn oxy-hydroxides in the lower anoxic water layer.

Depletion in dissolved oxygen at the SWI could also promote the reduction of As and subsequent desorption from $\mathrm{Fe}$ and Mn oxy-hydroxides (Smedley and Kinniburgh 2002) increasing dissolved As in the innermost sector of the estuary (2.97 and $2.31 \mu \mathrm{g} \mathrm{L}^{-1}$ in TV1 and TV2, respectively). In addition, McLaren and Kim (1995) stated that the increase in dissolved As could be the result of temperature-controlled microbial reduction of $\mathrm{As}(\mathrm{V})$ to $\mathrm{As}(\mathrm{III})$.

The relative importance of $\mathrm{N}$ and $\mathrm{P}$ in regulating the primary production is generally described by the DIN:SRP molar ratio (Ogrinc and Faganeli 2006; Roselli et al. 2009; Acquavita et al. 2015; Petranich et al. 2018a), which was found to be higher than 16 (Redfield et al. 1963) suggesting that the system was P-limited. The only exception is represented by the bottom marine water at site TV1, which showed a DIN:SRP molar ratio equal to only 2.30 . With regard to dissolved concentrations of both DIN and SRP, the European Environmental Agency (EEA 2001, 2003) has proposed four classes for the estimation of water quality ( $\mathrm{good}$, fair, poor and $b a d$ ). In the case of DIN, the estuarine water samples showed poor and bad water quality due to the elevated concentrations of $\mathrm{NO}_{3}{ }^{-}$, especially in the surface freshwater (Fig. 5). Regarding SRP, good water quality was found for most of the estuarine water samples with the lone exception of the bottom saline water at site TV1 which is of bad quality showing the highest value of SRP $\left(7.18 \mu \mathrm{mol} \mathrm{L}^{-1}\right)$ (Fig. 5).

Indeed, since the reductive forms of $\mathrm{N}$ prevail under anoxic conditions, a significant increase of $\mathrm{NO}_{2}{ }^{-}$and $\mathrm{NH}_{4}{ }^{+}$was evident in the bottom saltwater at site TV1. Here, denitrification 


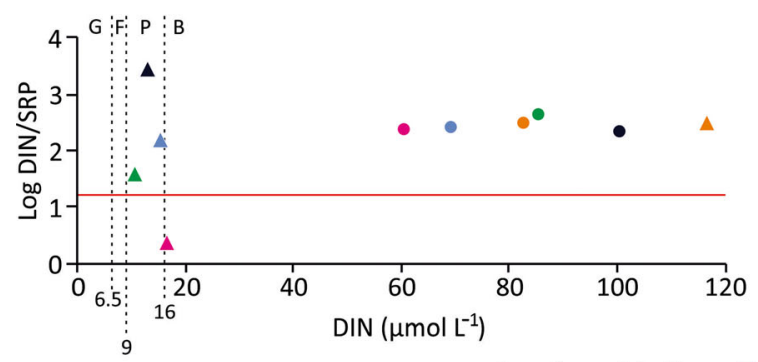

Osurface $\triangle$ bottom

Fig. 5 The DIN:SRP molar ratio (expressed on a logarithmic scale) plotted against dissolved concentrations of DIN and SRP measured at the estuarine system of the Timavo River. In both plots, water quality

processes and degradation of $\mathrm{OM}$ could result in a significant decrease in $\mathrm{NO}_{3}{ }^{-}$(Emili et al. 2011; Acquavita et al. 2015), the concentration of which was quite low at site TV1 (8.19 $\mu \mathrm{mol} \mathrm{L}^{-1}$ at the bottom), leading to an increase in $\mathrm{NH}_{4}{ }^{+}\left(7.78 \mu \mathrm{mol} \mathrm{L}{ }^{-1}\right.$ at the bottom). Moreover, the bottom saltwater also displayed a significant concentration of SRP, which is one order of magnitude higher $\left(7.18 \mu \mathrm{mol} \mathrm{L}^{-1}\right.$ at site TV1) compared to the other sampling sites and to the surface freshwater. Under these boundary conditions, the release of Fe and Mn has already been reported (Mason et al. 2006; Emili et al. 2011) and could originate from reduction-dissolution of particulate $\mathrm{Fe}$ and $\mathrm{Mn}$ oxy-hydroxides, Fe phosphate and $\mathrm{Fe}-$ $\mathrm{Mn}-\mathrm{P}$ particle aggregates sinking to the SWI (Dellwig et al. 2010).

\section{Trace Element Phase Partitioning Between the Suspended Particles and the Dissolved Fraction}

The trace element concentrations $\left(\mu \mathrm{g} \mathrm{g}^{-1}\right)$ in the suspended particles were found to be generally higher in the surface

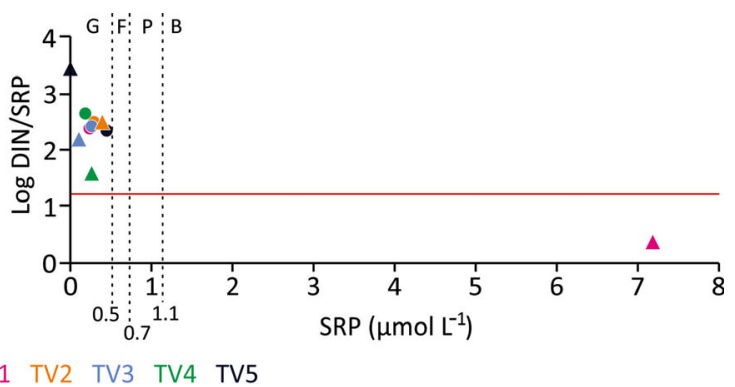

classification ( $\mathrm{G}=$ good, $\mathrm{F}=$ fair, $\mathrm{P}=$ =poor, $\mathrm{B}=$ bad) proposed by EEA (2001, 2003) was applied and the red line represents DIN:SRP $=16$ (Redfield et al. 1963)

freshwater than in the saltwater and the highest values were generally reached at site TV5 (Table S6). Particulate Mn was also notably present in the marine water ranging between $1056 \mu \mathrm{g} \mathrm{g}^{-1}$ (site TV3) and $3115 \mu \mathrm{g} \mathrm{g}{ }^{-1}$ (site TV1) most likely due to oxidation and precipitation processes promoted by high water temperatures (Morris et al. 1982; Hatje et al. 2001). This is consistent with previous research on the estuarine system of the Timavo River (Pavoni et al. 2020b) and other estuarine environments of the Gulf of Trieste (e.g. Sondi et al. 1994; Camusso et al. 1997; Pavoni et al. 2020a) reporting concentrations of particulate $\mathrm{Mn}$ of the same order of magnitude. Chromium and Ni reached the maximum concentrations at sites TV4 (280 and $247 \mu \mathrm{g} \mathrm{g}^{-1}$ of $\mathrm{Cr}$ and $\mathrm{Ni}$, respectively) and TV5 (351 and $308 \mu \mathrm{g} \mathrm{g}^{-1}$ of $\mathrm{Cr}$ and $\mathrm{Ni}$, respectively) suggesting that the river freshwater makes a notable contribution in the transportation of these elements towards the coastal zone. Chromium, $\mathrm{Ni}$ and $\mathrm{Co}$ are also strongly correlated in the SPM (Table 4) confirming their common lithogenic origin and the role of the Timavo River basin as their primary source (Pavoni et al. 2020b). Significant

Table 4 Pearson's correlation matrix for major and trace elements in the suspended particles at the estuarine system of the Timavo River. Bold numbers are used to indicate correlations with $P<0.05$ whereas bold and highlighted numbers indicate correlations with $P<0.01$

\begin{tabular}{|c|c|c|c|c|c|c|c|c|c|c|c|c|c|c|}
\hline & As & $\mathrm{Al}$ & $\mathrm{Ba}$ & $\mathrm{Co}$ & $\mathrm{Cr}$ & Cs & $\mathrm{Cu}$ & $\mathrm{Fe}$ & $\mathrm{Hg}$ & $\mathrm{Mn}$ & $\mathrm{Ni}$ & $\mathrm{Pb}$ & V & $\mathrm{Zn}$ \\
\hline As & 1 & & & & & & & & & & & & & \\
\hline $\mathrm{Al}$ & $\underline{0.843}$ & 1 & & & & & & & & & & & & \\
\hline $\mathrm{Ba}$ & $\underline{0.840}$ & $\underline{0.990}$ & 1 & & & & & & & & & & & \\
\hline Co & 0.641 & $\underline{0.815}$ & $\underline{0.809}$ & 1 & & & & & & & & & & \\
\hline $\mathrm{Cr}$ & $\underline{0.794}$ & $\underline{0.944}$ & $\underline{0.947}$ & $\underline{0.857}$ & 1 & & & & & & & & & \\
\hline Cs & 0.780 & $\underline{0.968}$ & 0.963 & 0.700 & $\underline{0.866}$ & 1 & & & & & & & & \\
\hline $\mathrm{Cu}$ & 0.151 & 0.183 & 0.296 & 0.221 & 0.376 & 0.174 & 1 & & & & & & & \\
\hline $\mathrm{Fe}$ & $\underline{0.866}$ & $\underline{0.997}$ & $\underline{0.986}$ & $\underline{0.796}$ & $\underline{0.933}$ & $\underline{0.961}$ & 0.149 & 1 & & & & & & \\
\hline $\mathrm{Hg}$ & 0.548 & $\underline{0.782}$ & $\underline{0.772}$ & 0.697 & $\underline{0.815}$ & 0.751 & 0.160 & $\underline{0.779}$ & 1 & & & & & \\
\hline $\mathrm{Mn}$ & -0.156 & -0.270 & -0.329 & -0.137 & -0.184 & -0.321 & -0.341 & -0.251 & -0.011 & 1 & & & & \\
\hline $\mathrm{Ni}$ & $\underline{0.797}$ & $\underline{0.950}$ & $\underline{0.945}$ & $\underline{0.864}$ & $\underline{0.997}$ & $\underline{0.866}$ & 0.315 & $\underline{0.942}$ & $\underline{0.825}$ & -0.136 & 1 & & & \\
\hline $\mathrm{Pb}$ & 0.647 & 0.667 & 0.714 & 0.564 & 0.789 & 0.585 & 0.578 & 0.659 & 0.437 & -0.360 & 0.755 & 1 & & \\
\hline V & $\underline{0.912}$ & $\underline{0.972}$ & $\underline{0.962}$ & $\underline{0.816}$ & $\underline{0.951}$ & $\underline{0.900}$ & 0.182 & 0.979 & 0.746 & -0.148 & $\underline{0.961}$ & 0.726 & 1 & \\
\hline $\mathrm{Zn}$ & 0.654 & 0.717 & 0.768 & 0.649 & 0.837 & 0.651 & 0.554 & 0.715 & $\underline{0.793}$ & -0.275 & 0.811 & $\underline{0.815}$ & 0.746 & 1 \\
\hline
\end{tabular}


correlations were also found between these elements and $\mathrm{Fe}(\mathrm{r}$ $=0.933, \mathrm{r}=0.942$ and $\mathrm{r}=0.796$ for $\mathrm{Cr}$, Ni and $\mathrm{Co}$, respectively) suggesting that oxidation and precipitation processes involving $\mathrm{Fe}$ oxy-hydroxides are responsible for trace element partitioning in the suspended particles. This is also evident for most of the other investigated trace elements (Table 4).

Since trace element behaviour is influenced by several physical and biogeochemical processes in estuaries, their sole concentration in the SPM is generally not enough to clearly describe their mobility and phase partitioning among solid and dissolved phases. The distribution coefficient $\left(K_{\mathrm{D}}, \mathrm{L} \mathrm{kg}^{-1}\right)$ represents a useful index for evaluating trace element fractionation between the dissolved fraction and the suspended particles (Turner 1996; EPA 1999; Gagnon and Saulnier 2003). In this research, $K_{\mathrm{D}}$ was expressed on a logarithmic scale and calculated according to Eq. (2), where $\mathrm{TE}_{\mathrm{SPM}}$ represents the trace element concentration $\left(\mu \mathrm{g} \mathrm{g}^{-1}\right)$ in the suspended particles and $\mathrm{TE}_{\mathrm{D}}$ is the dissolved concentration of the same trace element $(\mu \mathrm{g}$ $\mathrm{L}^{-1}$ ). The $\log K_{\mathrm{D}}$ was not calculated when the dissolved concentration was below LOD (Table 5).

$$
\log K_{\mathrm{D}}=\left(\left[\mathrm{TE}_{\mathrm{SPM}}\right] /\left[\mathrm{TE}_{\mathrm{D}}\right]\right)
$$

The $\log K_{\mathrm{D}}$ values were found to be generally high in the surface freshwater, especially at sites TV3, TV4 and TV5. The highest $\log K_{\mathrm{D}}$ values were reached by Fe since its high reactivity to the solid phase, as well as $\mathrm{Cu}, \mathrm{Hg}$ and $\mathrm{Pb}$ which were often found $<\mathrm{LOD}$ in the dissolved phase appearing to be almost completely partitioned in the SPM. Indeed, the surface freshwater is dominated by oxidative conditions which could promote oxidation and precipitation processes with subsequent trace element partitioning in the SPM. Although showing lower $\log K_{D}$ values, this is also evident in the bottom saltwater with the only exception being the innermost sector of the estuary (sites TV1 and TV2). There, water circulation is scarce and the reductive conditions at the bottom allowed desorption and/or dissolution processes of sinking $\mathrm{Fe}$ and $\mathrm{Mn}$ oxy-hydroxides promoting trace element partitioning in the dissolved phase. This is also confirmed by the low values of $\log K_{\mathrm{D}}$ at site TV1, which are equal to 3.85 and 5.74 for $\mathrm{Mn}$ and $\mathrm{Fe}$ and are generally low for several of the investigated trace elements (Table 5).

\section{Conclusions}

The estuarine system of the Timavo/Reka River was found to be heterogeneous in terms of occurrence and distribution of potentially toxic trace elements in spite of the limited
Table $5 \log K_{\mathrm{D}}$ values for $\mathrm{As}, \mathrm{Ba}, \mathrm{Co}, \mathrm{Cr}, \mathrm{Cs}, \mathrm{Cu}, \mathrm{Fe}, \mathrm{Hg}, \mathrm{Mn}, \mathrm{Ni}, \mathrm{Pb}$, $\mathrm{V}$ and $\mathrm{Zn}$ in water samples collected at the estuarine system of the Timavo River (n.d. not determined)

\begin{tabular}{|c|c|c|c|c|c|c|}
\hline Element & Layer & TV1 & TV2 & TV3 & TV4 & TV5 \\
\hline \multirow[t]{2}{*}{ As } & Surface & 4.58 & 4.77 & 4.86 & 5.00 & 4.90 \\
\hline & Bottom & 3.89 & 4.07 & 3.82 & 4.17 & 4.24 \\
\hline \multirow[t]{2}{*}{$\mathrm{Ba}$} & Surface & 4.10 & 3.94 & 4.21 & 4.17 & 4.26 \\
\hline & Bottom & 3.70 & 4.00 & 4.02 & 4.23 & 4.05 \\
\hline \multirow[t]{2}{*}{ Co } & Surface & 5.87 & 5.97 & 6.28 & 6.58 & 6.27 \\
\hline & Bottom & 4.61 & 5.06 & 5.24 & 5.38 & 5.41 \\
\hline \multirow[t]{2}{*}{$\mathrm{Cr}$} & Surface & 5.91 & 5.56 & 5.69 & 5.88 & 6.13 \\
\hline & Bottom & 5.85 & 5.47 & 5.02 & 5.21 & 5.74 \\
\hline \multirow[t]{2}{*}{ Cs } & Surface & 5.16 & 5.44 & 5.66 & 5.75 & 5.57 \\
\hline & Bottom & n.d. & 4.36 & 4.51 & 4.45 & n.d. \\
\hline \multirow[t]{2}{*}{$\mathrm{Cu}$} & Surface & 5.32 & n.d. & 5.25 & n.d. & n.d. \\
\hline & Bottom & n.d. & n.d. & 4.33 & n.d. & n.d. \\
\hline \multirow[t]{2}{*}{$\mathrm{Fe}$} & Surface & 6.95 & 6.84 & 7.16 & 7.51 & 7.41 \\
\hline & Bottom & 5.74 & 6.71 & 6.92 & 6.64 & 6.93 \\
\hline \multirow[t]{2}{*}{$\mathrm{Hg}$} & Surface & 5.94 & n.d. & n.d. & n.d. & n.d. \\
\hline & Bottom & 5.70 & n.d. & n.d. & n.d. & 6.66 \\
\hline \multirow[t]{2}{*}{$\mathrm{Mn}$} & Surface & 5.03 & 5.46 & 5.52 & 5.91 & 5.57 \\
\hline & Bottom & 3.85 & 5.16 & 4.97 & 5.08 & 5.29 \\
\hline \multirow[t]{2}{*}{$\mathrm{Ni}$} & Surface & 5.58 & 5.76 & 5.67 & 5.99 & 5.74 \\
\hline & Bottom & 4.75 & 5.06 & 4.92 & 5.02 & 5.07 \\
\hline \multirow[t]{2}{*}{ V } & Surface & 5.16 & 5.29 & 5.54 & 5.48 & 5.44 \\
\hline & Bottom & 4.41 & 4.62 & 4.51 & 4.79 & 4.76 \\
\hline \multirow[t]{2}{*}{$\mathrm{Pb}$} & Surface & n.d. & n.d. & n.d. & n.d. & n.d. \\
\hline & Bottom & n.d. & n.d. & n.d. & n.d. & n.d. \\
\hline \multirow[t]{2}{*}{$\mathrm{Zn}$} & Surface & n.d. & 5.37 & 5.26 & n.d. & n.d. \\
\hline & Bottom & n.d. & 4.77 & 4.09 & 4.68 & 4.29 \\
\hline
\end{tabular}

extension of the investigated area. Oxidation and precipitation processes prevailed in the surface freshwater driving to trace element partitioning in the suspended particles. The innermost sector represented by the East-West channel and its confluence with the Lòcavaz channel was recognised as the most critical area. There, elevated concentrations of potentially toxic trace elements were detected in the surface sediments and anoxic conditions at the SWI appear to be responsible for the removal of dissolved trace elements from the water column with a subsequent accumulation in sediments. However, recycling of sinking $\mathrm{Fe}$ and $\mathrm{Mn}$ oxy-hydroxides was thought to play a crucial role in the anoxic water layer. These results suggest that a better understanding of the chemical status of the innermost sector of this estuarine environment is needed. Specifically, future research should investigate trace elements speciation in sediments and along the water column, as well as biogeochemical fluxes of nutrients and potentially toxic trace elements at the SWI and their impact on the overlying water. 
Supplementary Information The online version contains supplementary material available at https://doi.org/10.1007/s12237-021-00910-9.

Acknowledgements This research activity was partially funded by Operational Programme 2014/2020 of the European Social Fund (ESF) of the Friuli Venezia Giulia Region, Italy (code FP1685623003). The authors want to thank Stefano Sponza and Gabriele Crevatin for their invaluable technical assistance during sampling. We warmly thank Karry Close for proofreading the manuscript.

Funding Open access funding provided by Università degli Studi di Trieste.

Open Access This article is licensed under a Creative Commons Attribution 4.0 International License, which permits use, sharing, adaptation, distribution and reproduction in any medium or format, as long as you give appropriate credit to the original author(s) and the source, provide a link to the Creative Commons licence, and indicate if changes were made. The images or other third party material in this article are included in the article's Creative Commons licence, unless indicated otherwise in a credit line to the material. If material is not included in the article's Creative Commons licence and your intended use is not permitted by statutory regulation or exceeds the permitted use, you will need to obtain permission directly from the copyright holder. To view a copy of this licence, visit http://creativecommons.org/licenses/by/4.0/.

\section{References}

Acquavita, A., S. Predonzani, G. Mattassi, P. Rossin, F. Tamberlich, J. Falomo, and I. Valic. 2010. Heavy metal contents and distribution in coastal sediments of the Gulf of Trieste (Northern Adriatic Sea, Italy). Water, Air, and Soil Pollution 211 (1-4): 95-111.

Acquavita, A., I.F. Aleffi, C. Benci, N. Bettoso, E. Crevatin, L. Milani, F. Tamberlich, L. Toniatti, P. Barbieri, S. Licen, and G. Matassi. 2015. Annual characterization of the nutrients and trophic state in a Mediterranean coastal lagoon: The Marano and Grado Lagoon (northern Adriatic Sea). Regional Studies in Marine Science 2: 132-144.

Adami, G., P. Barbieri, and E. Reisenhofer. 1999. A comparison on five sediment decomposition procedures for determining anthropogenic trace metal pollution. International Journal of Environmental Analytical Chemistry 75 (3): 251-260.

Adami, G., P. Barbieri, and E. Reisenhofer. 2000. An improved index for monitoring metal pollutants in surface sediments. Toxicological and Environmental Chemistry 77 (3-4): 189-197.

Algeo, T.J., and J.B. Maynard. 2004. Trace-element behavior and redox facies in core shales of Upper Pennsylvanian Kansas-type cyclothems. Chemical Geology 206 (3-4): 289-318.

Bloom, N.S., G.A. Gill, S. Cappellino, C. Dobbs, L. McShea, C. Driscoll, R. Mason, and J. Rudd. 1999. Speciation and cycling of mercury in Lavaca Bay, Texas, sediments. Environmental Science and Technology 33 (1): 7-13.

Botwe, B.O., P. Kelderman, E. Nyarko, and P.N.L. Lens. 2017. Assessment of DDT, HCH and PAH contamination and associated ecotoxicological risks in surface sediments of coastal Tema Harbour (Ghana). Marine Pollution Bulletin 115 (1-2): 480-488.

Calligaris, C., K. Mezga, F.F. Slejko, J. Urbanc, and L. Zini. 2018. Groundwater characterization by means of conservative $\left(\delta^{18} \mathrm{O}\right.$ and $\left.\delta^{2} \mathrm{H}\right)$ and non-conservative $\left({ }^{87} \mathrm{Sr} /{ }^{86} \mathrm{Sr}\right)$ isotopic values: The classical karst region aquifer case (Italy-Slovenia). Geosciences 8 (9): 321.

Camusso, M., S. Crescenzio, W. Martinotti, M. Pettine, and R. Pagnotta. 1997. Behaviour of Co, Fe, Mn and Ni in the Po estuary (Italy). Water, Air, and Soil Pollution 99 (1-4): 297-304.

Caplat, C., H. Texier, D. Barillier, and C. Lelievre. 2005. Heavy metals mobility in harbour contaminated sediments: The case of Port-enBessin. Marine Pollution Bulletin 50 (5): 504-511.

Casado-Martínez, M.C., J.L. Buceta, M.J. Belzunce, and T.A. DelValls. 2006. Using sediment quality guidelines for dredged material management in commercial ports from Spain. Environment International 32 (3): 388-396.

Cerovac, A., S. Covelli, A. Emili, E. Pavoni, E. Petranich, A. Gregorič, J. Urbanc, E. Zavagno, and L. Zini. 2018. Mercury in the unconfined aquifer of the Isonzo/Soča River alluvial plain downstream from the Idrija mining area. Chemosphere 195: 749-761.

Cibic, T., A. Acquavita, F. Aleffi, N. Bettoso, O. Blasutto, C. De Vittor, C. Falconi, J. Falomo, L. Faresi, S. Predonzani, F. Tamberlich, and S. Fonda Umani. 2008. Integrated approach to sediment pollution: A case study in the Gulf of Trieste. Marine Pollution Bulletin 56 (9): $1650-1657$.

Cossa, D., X. Durrieu de Madron, J. Schäfer, L. Lanceleur, S. Guédron, R. Buscail, B. Thomas, S. Castelle, and J.J. Naudin. 2017. The open sea as the main source of methylmercury in the water column of the Gulf of Lions (Northwestern Mediterranean margin). Geochimica et Cosmochimca Acta 199: 222-237.

Covelli, S., and G. Fontolan. 1997. Application of a normalization procedure in determining regional geochemical baselines. Environmental Geology 30 (1-2): 34-45.

Covelli, S., J. Faganeli, M. Horvat, and A. Brambati. 2001. Mercury contamination of coastal sediments as the result of long-term cinnabar mining activity (Gulf of Trieste, northern Adriatic sea). Applied Geochemistry 16 (5): 541-558.

Covelli, S., G. Fontolan, J. Faganeli, and N. Ogrinc. 2006. Anthropogenic markers in the Holocene stratigraphic sequence of the Gulf of Trieste (northern Adriatic Sea). Marine Geology 230 (1-2): 29-51.

Covelli, S., R. Piani, A. Acquavita, S. Predonzani, and J. Faganeli. 2007. Transport and dispersion of particulate $\mathrm{Hg}$ associated with a river plume in coastal Northern Adriatic environments. Marine Pollution Bulletin 55 (10-12): 436-450.

Cozzi, S., C. Falconi, C. Comici, B. Čermelj, N. Kovac, V. Turk, and M. Giani. 2012. Recent evolution of river discharges in the Gulf of Trieste and their potential response to climate changes and anthropogenic pressure. Estuarine, Coastal and Shelf Science 115: 14-24.

Cucchi, F., F. Giorgietti, E. Marinetti, and A. Kranjc. 1997. Experiences in monitoring Timavo River (Classical Karst). Tracer Hydrology 97: $167-172$

de Souza Machado, A.A., K. Spencer, W. Kloas, M. Toffolon, and C. Zarfl. 2016. Metal fate and effects in estuaries: A review and conceptual model for better understanding of toxicity. Science of the Total Environment 541: 268-281.

De Vittor, C., J. Faganeli, A. Emili, S. Covelli, S. Predonzani, and A. Acquavita. 2012. Benthic fluxes of oxygen, carbon and nutrients in the Marano and Grado Lagoon (northern Adriatic Sea, Italy). Estuarine, Coastal and Shelf Science 113: 57-70.

Dellwig, O., T. Leipe, C. März, M. Glockzin, F. Pollehne, B. Schnetger, E.V. Yakushev, M.E. Böttcher, and H.J. Brumsack. 2010. A new particulate $\mathrm{Mn}-\mathrm{Fe}-\mathrm{P}$-shuttle at the redoxcline of anoxic basins. Geochimica et Cosmochimica Acta 74 (24): 7100-7115.

Doctor, D.H., S. Lojen, and M. Horvat. 2000. A stable isotope investigation of the classical karst aquifer: Evaluating karst groundwater components for water quality preservation. Acta Carsologica 29: 79-92.

Dolenec, T., J. Faganeli, and S. Pirc. 1998. Major, minor and trace elements in surficial sediments from the open Adriatic Sea: a regional geochemical study. Geologia Croatica 51 (1): 47-58. 
Dyrssen, D. 1996. The anoxic bottom waters of the Black Sea and Framvaren - Similarities and differences. GFF 118 (2): 115-117.

EEA. 2001. Eutrophication in Europe's Coastal Waters, Topic Report no. 1/2003, 97. Copenhagen: European Environmental Agency.

EEA. 2003. Europe's Water: An Indicator-based Assessment. Topic Report no. 7. European Environmental Agency WWW Page, http://www.eea.europa.eu.

Eggleton, J., and K.V. Thomas. 2004. A review of factors affecting the release and bioavailability of contaminants during sediment disturbance events. Environment International 30 (7): 973-980.

Emili, A., N. Koron, S. Covelli, J. Faganeli, A. Acquavita, S. Predonzani, and C. De Vittor. 2011. Does anoxia affect mercury cycling at the sediment-water interface in the Gulf of Trieste (northern Adriatic Sea)? Incubation experiments using benthic flux chambers. Applied Geochemistry 26 (2): 194-204.

Emili, A., L. Carrasco, A. Acquavita, and S. Covelli. 2014. A laboratoryincubated redox oscillation experiment to investigate $\mathrm{Hg}$ fluxes from highly contaminated coastal marine sediments (Gulf of Trieste, Northern Adriatic Sea). Environmental Science and Pollution Research 21 (6): 4124-4133.

Emili, A., A. Acquavita, S. Covelli, L. Spada, A. Di Leo, S. Giandomenico, and N. Cardellicchio. 2016. Mobility of heavy metals from polluted sediments of a semi-enclosed basin: In situ benthic chamber experiments in Taranto's Mar Piccolo (Ionian Sea, Southern Italy). Environmental Science and Pollution Research 23 (13): 12582-12595.

EPA. 1996. EPA Method 3052, 20. Microwave assisted acid digestion of siliceous and organically based matrices.

EPA. 1999. Understanding variation in partition coefficient, Kd, values, II, 341. EPA 402-R99-004B.

EPA. 2002. EPA Method 1631, Revision E. Mercury in water by oxidation, purge and trap, and cold vapor atomic fluorenscence spectrometry, p. 22.

Faganeli, J., R. Planinc, J. Pezdič, B. Smodiš, P. Stegnar, and B. Ogorelec. 1991. Marine geology of the Gulf of Trieste (northern Adriatic): Geochemical aspects. Marine Geology 99 (1-2): 93-108.

Fiket, Ž., M. Ivanić, M.F. Turk, N. Mikac, and G. Kniewald. 2018. Distribution of trace elements in waters of the zrmanja river estuary (eastern adriatic coast, croatia). Croatica Chemica Acta 91 (1): 2941.

Frančišković-Bilinski, S., R. Scholger, H. Bilinski, and D. Tibljaš. 2014. Magnetic, geochemical and mineralogical properties of sediments from karstic and flysch rivers of Croatia and Slovenia. Environmental Earth Sciences 72 (19): 3939-3953.

Froelich, P.N., G.P. Klinkhammer, M.L. Bender, N.A. Luedtke, G.R. Heath, D. Cullen, P. Dauphin, D. Hammond, B. Hartman, and V. Maynard. 1979. Early oxidation of organic matter in pelagic sediments of the eastern equatorial Atlantic: Suboxic diagenesis. Geochimica et Cosmochimica Acta 43 (7): 1075-1090.

Gabrovšek, F., and B. Peric. 2006. Monitoring the flood pulses in the epiphreatic zone of karst aquifers: The case of Reka river system, Karst plateau, SW Slovenia. Acta Carsologica 35 (1): 35-45.

Gabrovšek, F., B. Peric, and G. Kaufmann. 2018. Hydraulics of epiphreatic flow of a karst aquifer. Journal of Hydrology 560: 5674.

Gagnon, C., and I. Saulnier. 2003. Distribution and fate of metals in the dispersion plume of a major municipal effluent. Environmental Pollution 124 (1): 47-55.

Gleyzes, C., S. Tellier, and M. Astruc. 2002. Fractionation studies of trace elements in contaminated soils and sediments: A review of sequential extraction procedures. Trends in Analytical Chemistry 21 (6-7): 451-467.

Grasshoff, K., M. Ehrhardt, and K. Kremling. 1999. Methods of seawater analyses, 419. Verlag Chemie: Weinheim.
Haraldsson, C., and S. Westerlund. 1988. Trace metals in the water columns of the Black Sea and Framvaren Fjord. Marine Chemistry 23 (3-4): 417-424.

Hatje, V., G.F. Birch, and D.M. Hill. 2001. Spatial and temporal variability of particulate trace metals in Port Jackson Estuary, Australia. Estuarine, Coastal and Shelf Science 53 (1): 63-77.

Hines, M.E., M. Horvat, J. Faganeli, J.C.J. Bonzongo, T. Barkay, E.B. Major, K.J. Scott, E.A. Bailey, J.J. Warwick, and W.B. Lyons. 2000. Mercury biogeochemistry in the Idrija River, Slovenia, from above the mine into the Gulf of Trieste. Environmental Research 83 (2): 129-139.

Horvat, M., S. Covelli, J. Faganeli, M. Logar, V. Mandić, R. Rajar, A. Šrca, and D. Žagar. 1999. Mercury in contaminated coastal environments; a case study: The Gulf of Trieste. Science of the Total Environment 237-238: 43-56.

Huerta-Diaz, M.A., and J.W. Morse. 1992. Pyritization of trace metals in anoxic marine sediments. Geochimica et Cosmochimica Acta 56 (7): 2681-2702.

Konovalov, S., A. Samodurov, T. Oguz, and L. Ivanov. 2004. Parameterization of iron and manganese cycling in the Black Sea suboxic and anoxic environment. Deep-Sea Research Part I: Oceanographic Research Papers 51 (12): 2027-2045.

Kovač, N., N. Glavaš, T. Ramšak, M. Dolenec, and N. Rogan Šmuc. 2018. Metal(oid) mobility in a hypersaline salt marsh sediment (Sečovlje Salina, northern Adriatic, Slovenia). Science of the Total Environment 644: 350-359.

Leardi, R., C. Melzi, and G. Polotti. 2019. CAT (Chemometric Agile Tool), freely downloadable from http://gruppochemiometria.it/ index.php/software. Accessed September 3rd, 2019).

Lenaz, D., and F. Princivalle. 1996. Crystal-chemistry of detrital chromites in sandstones from Trieste (NE Italy). Neues Jahrbuch fur Mineralogie, Monatshefte 9: 429-434.

Lenaz, D., S. Carbonin, M. Gregoric, and F. Princivalle. 2002. Crystal chemistry and oxidation state of one euhedral Cr-spinel crystal enclosed in a bauxite layer (Trieste Karst: NE Italy): Some considerations on its depositional history and provenance. Neues Jahrbuch fur Mineralogie, Monatshefte 5: 193-206.

Malačič, V., and B. Petelin. 2009. Climatic circulation in the Gulf of Trieste (northern Adriatic). Journal of Gophysical Research: Oceans 114 (7): C07002.

Mason, R.P., E.H. Kim, J. Cornwell, and D. Heyes. 2006. An examination of the factors influencing the flux of mercury, methylmercury and other constituents from estuarine sediment. Marine Chemistry 102 (1-2): 96-110.

McKee, B., and J. Skei. 1999. Framvaren Fjord as a natural laboratory for examining biogeochemical processes in anoxic environments: Introduction. Marine Chemistry 67 (3-4): 147-148.

McLaren, S.J., and N.D. Kim. 1995. Evidence for a seasonal fluctuation of arsenic in New Zeland's longest river and the effect of treatment on concentrations in drinking water. Environmental Pollution 90 (1): 67-73.

Meade, R.H. 1972. Transport and dispersion of sediments in estuaries. Memoir - Geological Society of America 133: 90-120.

Menon, M.G., R.J. Gibbs, and A. Phillips. 1998. Accumulation of muds and metals in the Hudson River estuary turbidity maximum. Environmental Geology 34 (2-3): 214-222.

Monterroso, P., P. Pato, M.E. Pereira, G.E. Millward, C. Vale, and A. Duarte. 2007. Metal-contaminated sediments in a semi-closed basin: Implications for recovery. Estuarine, Coastal and Shelf Science 71 (1-2): 148-158.

Morris, A.W., A.J. Bale, and R.J.M. Howland. 1982. Chemical variability in the Tamar Estuary, south-west England. Estuarine, Coastal and Shelf Science 14 (6): 649-661.

Neto, J.A.B., F.X. Gingele, T. Leipe, and I. Brehme. 2006. Spatial distribution of heavy metals in surficial sediments from Guanabara Bay: Rio de Janeiro, Brazil. Environmental Geology 49 (7): 1051-1063. 
Ogrinc, N., and J. Faganeli. 2006. Phosphorus regeneration and burial in near-shore marine sediments (the Gulf of Trieste, northern Adriatic Sea). Estuarine, Coastal and Shelf Science 67 (4): 579-588.

Oliveri, P., C. Malegori, R. Simonetti, and M. Casale. 2019. The impact of signal pre-processing on the final interpretation of analytical outcomes - A tutorial. Analytica Chimica Acta 1058: 9-17.

Oliveri, P., C. Malegori, and M. Casale. 2020. Chemometrics: Multivariate Analysis of Chemical Data. In Chemical analysis of food, ed. Y. Pico, 2nd ed. Elsevier ISBN 9780128132661.

Olivotti, R., J. Faganeli, and A. Malej. 1986. Impact of "organic" pollutants on coastal waters, Gulf of Trieste. Water Science and Technology 18 (9): 57-68.

Ospina-Alvarez, N., Ł. Głaz, K. Dmowski, and B. KrasnodębskaOstrega. 2014. Mobility of toxic elements in carbonate sediments from a mining area in Poland. Environmental Chemistry Letters 12 (3): 435-441.

Pavoni, E., M. Crosera, E. Petranich, G. Adami, J. Faganeli, and S. Covelli. 2020a. Partitioning and mixing behaviour of trace elements at the Isonzo/Soča River mouth (Gulf of Trieste, northern Adriatic Sea). Marine Chemistry 223: 103800.

Pavoni, E., M. Crosera, E. Petranich, P. Oliveri, K. Klun, J. Faganeli, S. Covelli, and G. Adami. 2020b. Trace elements in the estuarine systems of the Gulf of Trieste (northern Adriatic Sea): A chemometric approach to depict partitioning and behaviour of particulate, colloidal and truly dissolved fractions. Chemosphere 252: 126517.

Petranich, E., S. Covelli, A. Acquavita, C. De Vittor, J. Faganeli, and M. Contin. 2018a. Benthic nutrient cycling at the sediment-water interface in a lagoon fish farming system (northern Adriatic Sea, Italy). Science of the Total Environment 644: 137-149.

Petranich, E., S. Croce, M. Crosera, E. Pavoni, J. Faganeli, G. Adami, and S. Covelli. 2018b. Mobility of metal(loid)s at the sediment-water interface in two tourist port areas of the Gulf of Trieste (northern Adriatic Sea). Environmental Science and Pollution Research 25 (27): 26887-26902.

Piou, S., P. Bataillard, A. Laboudigue, J.F. Férard, and J.F. Masfaraud. 2009. Changes in the geochemistry and ecotoxicity of a $\mathrm{Zn}$ and $\mathrm{Cd}$ contaminated dredged sediment over time after land disposal. Environmental Research 109 (6): 712-720.

Point, D., M. Monperrus, E. Tessier, D. Amouroux, L. Chauvaud, G. Thouzeau, F. Jean, E. Amice, J. Grall, A. Leynaert, J. Clavier, and O.F.X, Donard. 2007. Biological control of trace metal and organometal benthic fluxes in a eutrophic lagoon (Thau Lagoon, Mediterranean Sea, France). Estuarine, Coastal and Shelf Science 72 (3): 457-471.

Redfield, A.C., B.A. Ketcum, and F.A. Richards. 1963. The influence of organisms in the composition of seawater. In The Sea: Ideas and Observations on Progress in the Study of The Seas, ed. M.N. Hill, vol. 2, 26-77. New York: Interscience.

Reisenhofer, E., G. Adami, and P. Barbieri. 1996. Trace metals used as natural markers for discriminating some karstic freshwater near Trieste (Italy). Toxicological and Environmental Chemistry 54 (14): $233-241$.

Reisenhofer, E., G. Adami, and P. Barbieri. 1998. Using chemical and physical parameters to define the quality of karstic freshwaters (Timavo River, North-eastern Italy): A chemometric approach. Water Research 32 (4): 1193-1203.

Riedel, G.F., J.G. Sanders, and R.W. Osman. 1999. Biogeochemical control on the flux of trace elements from estuarine sediments: Effects of seasonal and short-term hypoxia. Marine Environmental Research 47 (4): 349-372.

Roselli, L., A. Fabbrocini, C. Manzo, and R. D'Adamo. 2009. Hydrological heterogeneity, nutrient dynamics and water quality of a non-tidal lentic ecosystem (Lesina Lagoon, Italy). Estuarine, Coastal and Shelf Science 84 (4): 539-552.

Sahuquillo, A., A. Rigol, and G. Rauret. 2003. Overview of the use of leaching/extraction tests for risk assessment of trace metals in contaminated soils and sediments. Trends in Analytical Chemistry 22 (3): $152-159$.

Santos-Echeandia, J., R. Prego, A. Cobelo-García, and G.E. Millward. 2009. Porewater geochemistry in a Galician Ria (NW Iberian Peninsula): Implications for benthic fluxes of dissolved trace elements (Co, Cu, Ni, Pb, V, Zn). Marine Chemistry 117 (1-4): 77-87.

Savenko, A.V., V.F. Brekhovskikh, and O.S. Pokrovskii. 2014. Migration of dissolved trace elements in the mixing zone between Volga River water and Caspian seawater: Results of observations over many years. Geochemistry International 52 (7): 533-547.

Scholz, F., J. McManus, and S. Sommer. 2013. The manganese and iron shuttle in a modern euxinic basin and implications for molybdenum cycling at euxinic ocean margins. Chemical Geology 355: 56-68.

Shaheen, S.M., T. Frohne, J.R. White, R.D. DeLaune, and J. Rinklebe. 2017. Redox-induced mobilization of copper, selenium, and zinc in deltaic soils originating from Mississippi (U.S.A.) and Nile (Egypt) River Deltas: A better understanding of biogeochemical processes for safe environmental management. Journal of Environmental Management 186 (Pt 2): 131-140.

Shepard, F.P. 1954. Nomenclature based on sand-silt-clay ratios. Journal of Sedimentary Petrology 24: 151-158.

Sigg, L., H. Xue, D. Kistler, and R. Sshönenberger. 2000. Size fractionation (dissolved, colloidal and particulate) of trace metals in the Thur river, Switzerland. Aquatic Geochemistry 6 (4): 413-434.

Silveira, A.E.F., J.R. Nascimento, E. Sabadini-Santos, and E.D. Bidone. 2017. Screening-level risk assessment applied to dredging of polluted sediments from Guanabara Bay, Rio de Janeiro, Brazil. Marine Pollution Bulletin 118 (1-2): 368-375.

Siot, V., T. Guérin, Y. Mauras, H. Garraud, J.L. Volatier, and J.C. Leblanc. 2008. Methylmercury exposure assessment using dietary and biomarker data among frequent seafood consumers in France. CALIPSO study. Environmental Research 107 (1): 30-38.

Smedley, P.L., and D.G. Kinniburgh. 2002. A review of the source, behaviour and distribution of arsenic in natural waters. Applied Geochemistry 17 (5): 517-568.

Šmuc, N.R., M. Dolenec, S. Kramar, and A. Mladenović. 2018. Heavy metal signature and environmental assessment of nearshore sediments: Port of koper (northern adriatic sea). Geosciences 8 (11): 398.

Sondi, I., M. Juračić, E. Prohíć, and V. Pravdić. 1994. Particulates and the environmental capacity for trace metals. A small river as a model for a land-sea transfer system: the Raša River estuary. Science of the Total Environment 155 (2): 173-185.

Sugimura, Y., and Y. Suzuki. 1998. A high temperature catalytic oxidation method for the determination of non-volatile dissolved organic carbon in seawater by direct injection of liquid sample. Marine Chemistry 24 (2): 105-131.

Sutherland, R.A. 2000. Bed sediment-associated trace metals in an urban stream, Oahu, Hawaii. Environmental Geology 39 (6): 611-627.

Tribovillard, N., T.J. Algeo, T. Lyons, and A. Riboulleau. 2006. Trace metals as paleoredox and paleoproductivity proxies: An update. Chemical Geology 232 (1-2): 12-32.

Turner, A. 1996. Trace-metal partitioning in estuaries: Importance of salinity and particle concentration. Marine Chemistry 54 (1-2): 27-39.

Turner, R.E., W.W. Schroeder, and W.M.J. Wiseman. 1987. The role of stratification in the deoxygenation of Mobile Bay and adjacent shelf bottom waters. Estuaries 10 (1): 13-19. 
Turner, A., G.E. Millward, and A.W. Morris. 1991. Particulate metals in five major North Sea estuaries. Estuarine, Coastal and Shelf Science 32 (4): 325-346.

Warnken, K.W., G.A. Gill, L.L. Griffin, and P.H. Santschi. 2001. Sediment-water exchange of $\mathrm{mn}, \mathrm{fe}$, ni and $\mathrm{zn}$ in galveston bay, texas. Marine Chemistry 73 (3-4): 215-231.

Wasserman, J.C., M.A.V. Wasserman, P.R.G. Barrocas, and A.M. Almeida. 2016. Predicting pollutant concentrations in the water column during dredging operations: Implications for sediment quality criteria. Marine Pollution Bulletin 108 (1-2): 24-32.

Wright, L.D. 1977. Sediment transport and deposition at river mouths: A synthesis. Bulletin of the Geological Society of America 88 (6): 857 868.
Yao, W., and F.J. Millero. 1995. The chemistry of the anoxic waters in the Framvaren Fjord, Norway. Aquatic Geochemistry 1 (1): 53-88.

Yao, Q., X. Wang, H. Jian, H. Chen, and Z. Yu. 2016. Behavior of suspended particles in the Changjiang Estuary: Size distribution and trace metal contamination. Marine Pollution Bulletin 103 (12): $159-167$

Zonta, R., D. Cassin, R. Pini, and J. Dominik. 2019. Assessment of heavy metal and As contamination in the surface sediments of Po delta lagoons (Italy). Estuarine, Coastal and Shelf Science 225: 106235.

Zupančič, N., and S. Skobe. 2014. Anthropogenic environmental impact in the Mediterranean coastal area of Koper/Capodistria, Slovenia. Journal of Soils and Sediments 14 (1): 67-77. 